\title{
PNEUMATIC TESTING IN 45-DEGREE-INCLINED BOREHOLES IN ASH-FLOW TUFF NEAR SUPERIOR, ARIZONA
}

\section{U.S. GEOLOGICAL SURVEY}

Water-Resources Investigations Report 95-4073

\section{RECEIVED \\ OCT 251995 \\ OSTI}

Prepared in cooperation with the NEVADA OPERATIONS OFFICE

U.S. DEPARTMENT OF ENERGY under

(Interagency Agreement DE-AI08-92NV10874)

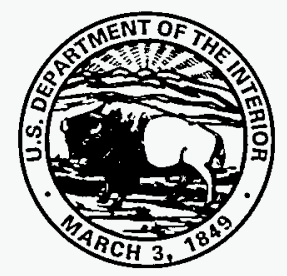





\title{
PNEUMATIC TESTING IN 45-DEGREE-INCLINED BOREHOLES IN ASH-FLOW TUFF NEAR SUPERIOR, ARIZONA
}

\author{
by Gary D. LeCain
}

\section{U.S. GEOLOGICAL SURVEY}

Water-Resources Investigations Report 95-4073

Prepared in cooperation with the

NEVADA OPERATIONS OFFICE, U.S. DEPARTMENT OF ENERGY under

(Interagency Agreement DE-Al08-92NV10874)

\section{DISCLAIMER}

This report was prepared as an account of work sponsored by an agency of the United States Government. Neither the United States Government nor any agency thereof, nor any of their employees, makes any warranty, express or implied, or assumes any legal liability or responsibility for the accuracy, completeness, or usefulness of any information, apparatus, product, or process disclosed, or represents that its use would not infringe privately owned rights. Reference herein to any specific commercial product, process, or service by trade name, trademark, manufacturer, or otherwise does not necessarily constitute or imply its endorsement, recommendation, or favoring by the United States Government or any agency thereof. The views and opinions of authors expressed herein do not necessarily state or reflect those of the United States Government or any agency thereof.

Denver, Colorado 1995

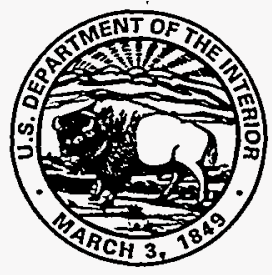




\section{U.S. DEPARTMENT OF THE INTERIOR \\ BRUCE BABBITT, Secretary}

U.S. GEOLOGICAL SURVEY

Gordon P. Eaton, Director

The use of trade, product, industry, or firm names is for descriptive purposes only and does not imply endorsement by the U.S. Government.

For additional information write to: Chief, Earth Science Investigations Program

Yucca Mountain Project Branch

U.S. Geological Survey

Box 25046, MS 421

Denver Federal Center

Denver, CO 80225
Copies of this report can be purchased from: U.S. Geological Survey

Earth Science Information Center

Open-File Reports Section

Box 25286, MS 517

Denver Federal Center

Denver, CO 80225 


\section{CONTENTS}

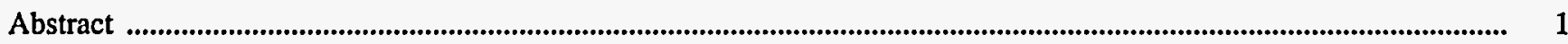

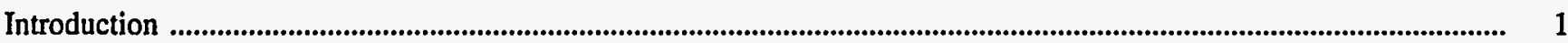

Purpose and scope ........................................................................................................................................................ 2

Location of study area ....................................................................................................................................................... 2

Climate .................................................................................................................................................... 2

Physiography ........................................................................................................................................................................ 2

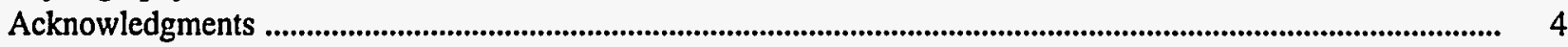

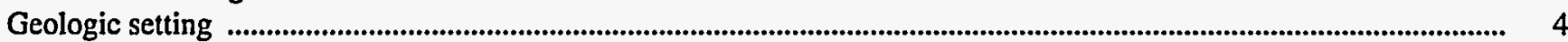



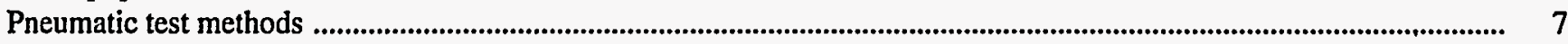

Single-hole gas-injection testing ............................................................................................................................... 7

Cross-hole gas-injection and recovery testing ................................................................................................... 8

Pneumatic test analysis ..................................................................................................................................................................... 8

Steady-state analysis ......................................................................................................................................................... 10

Semilog analysis .............................................................................................................................................................. 11

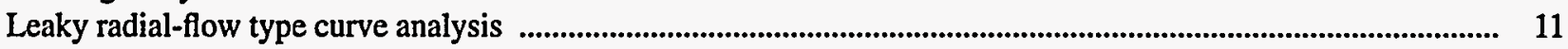

Spherical-flow type curve analysis ................................................................................................................................ 12

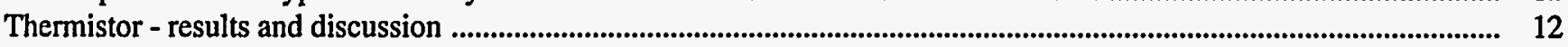

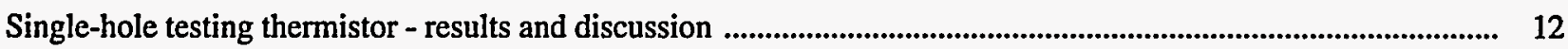

Cross-hole testing thermistor - results and discussion ..................................................................................... 14

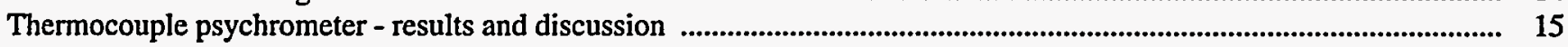

Single-hole testing thermocouple psychrometer - results and discussion .................................................................. 15

Cross-hole testing thermocouple psychrometer - results and discussion ................................................................... 15

Pneumatic testing - results and discussion ........................................................................................................................... 17

Single-hole pneumatic testing - results and discussion ........................................................................................... 17

Cross-hole pneumatic testing - results and discussion .......................................................................................... 20

Summary ................................................................................................................................................................................. 24

Thermistors ............................................................................................................................................................................. 24

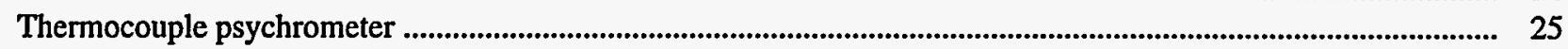

Single-hole pneumatic testing ................................................................................................................................. 25

Cross-hole pneumatic testing ........................................................................................................................................... 26

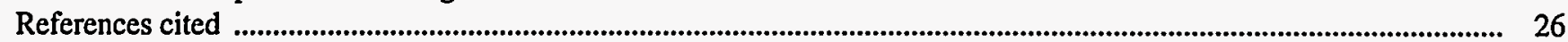

\section{FIGURES}

1. Location of test site near Superior, Arizona ............................................................................................... 3

2. Schematic of single-hole gas-injection testing using a 4-packer packer assembly .............................................. 5

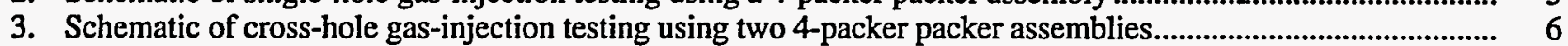

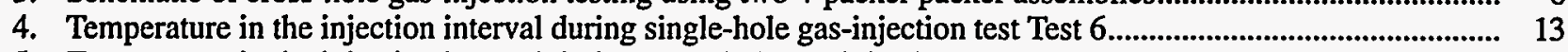

5. Temperature in the injection interval during cross-hole gas-injection and recovery tests Inject 1 and Recov 1

6. Dry-bulb readings from thermocouple psychrometers during cross-hole gas-injection and

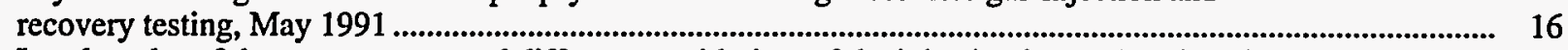

7. Log-log plot of the pressure-squared differences with time of the injection interval during single-hole gas-injection test Test 6, and the Ramey (1967) and van Everdingen and Hurst (1949) type curves................... 18

8. Log-log plot of the pressure-squared differences with time of the injection interval during cross-hole gas-injection test Inject 3 , and the Cooper (1963) type curves for $v=0.0$ and $v=0.25$.

9. Log-log plot of the pressure-squared differences with time of monitor interval M1 during gas-injection test

10. Semilog plot of the pressure-squared differences with time of the injection interval during test 3 a curves ......... 21 Inject 3 showing the straight-line radial flow period. 


\section{TABLES}

1. Temperature changes in the injection interval during December 1990 single-hole gas-injection testing ................ 13

2. Initial and long-term temperature changes in the injection interval during May 1991 cross-hole gas-injection and recovery testing...

3. Permeability test results of three analysis methods of single-hole gas-injection testing using air and nitrogen, December 1990

4. F-distribution significance at the 0.05 level, and p-values, for a two-way analysis of variance of single-hole testing permeability values using paired injection rates of air and nitrogen

5. Correlation coefficients, and $t$-test significance at the 0.05 level, of injection rate with permeability and test order with permeability for single-hole gas-injection testing.

6. Permeability test results of cross-hole gas-injection and recovery testing, May 1991

7. F-distribution significance at the 0.05 level, and p-values, for a two-way analysis of variance of cross-hole testing permeability values using paired gas-injection and recovery tests

8. Correlation coefficients, and $t$-test significance at the 0.05 level, of injection rate with permeability and test order with permeability for cross-hole gas-injection and recovery testing

9. Porosity values from cross-hole gas-injection and recovery testing, May 1991

10. F-distribution significance at the 0.05 level, and p-values, for a two-way analysis of variance of porosity using paired gas-injection and recovery tests

11. Correlation coefficients, and t-test significance at the 0.05 level, of injection rate with porosity and test order with porosity for cross-hole gas-injection and recovery testing.

\section{CONVERSION FACTORS AND VERTICAL DATUM}

\begin{tabular}{rcl} 
Multiply & By & To obtain \\
\hline centimeter $(\mathrm{cm})$ & 0.3937 & \\
cubic meters per second $\left(\mathrm{m}^{3} / \mathrm{s}\right)$ & $15,852.0$ & inch \\
kilogram $(\mathrm{kg})$ & 2.205 & gallons per minute \\
kilometer $(\mathrm{km})$ & 0.6214 & pound avoirdupois \\
kilopascal $(\mathrm{kPa})$ & 0.145 & mile \\
meter $(\mathrm{m})$ & 3.281 & pound-force per square inch \\
meters squared $\left(\mathrm{m}^{2}\right)$ & 10.765 & foot \\
metric ton & 0.892 & foot squared \\
micron & $10^{-6}$ & ton (short) \\
millimeters & 0.0394 & meter \\
Pascal seconds $\left(\mathrm{Pa}^{*}\right)$ & 10.0 & inch \\
standard liters per minute $(\mathrm{slpm})^{*}$ & 0.2642 & poise \\
& & gallons per minute \\
\hline
\end{tabular}

In this report, the term standard, when used with respect to volumetric gas measurements, means a measurement taken at a temperature of 0 degrees Celsius and atmospheric pressure of 101.3 kiloPascals.

Temperatures are in degree Celsius. Degree Celsius $\left({ }^{\circ} \mathrm{C}\right)$ may be converted to degree Fahrenheit $\left({ }^{\circ} \mathrm{F}\right)$ by using the following equation:

$$
{ }^{\circ} \mathrm{F}=9 / 5\left({ }^{\circ} \mathrm{C}\right)+32 .
$$

The permeability equations use degree Kelvin. Degree Kelvin $\left({ }^{\circ} \mathrm{K}\right)$ may be converted to degree Fahrenheit $\left({ }^{\circ} \mathrm{F}\right)$ by using the following equation:

$$
{ }^{\circ} \mathrm{F}=9 / 5\left({ }^{\circ} \mathrm{K}\right)-459.67 .
$$

Sea level: In this report "sea level" refers to the National Geodetic Vertical Datum of 1929 (NGVD of 1929) -a geodetic datum derived from a general adjustment of the first-order level nets of both the United States and Canada, formerly called Sea Level Datum of 1929. 


\title{
Pneumatic Testing in 45-Degree-Inclined Boreholes in Ash-Flow Tuff Near Superior, Arizona
}

\author{
ByGary D. LeCain
}

\begin{abstract}
Matrix permeability values determined by single-hole pneumatic testing in nonfractured ashflow tuff ranged from 5.1 to $20.3 * 10^{-16} \mathrm{~m}^{2}$ (meters squared), depending on the gas-injection rate and analysis method used. Results from the singlehole tests showed several significant correlations between permeability and injection rate and between permeability and test order. Fracture permeability values determined by cross-hole pneumatic testing in fractured ash-flow tuff ranged from 0.81 to $3.49 * 10^{-14} \mathrm{~m}^{2}$, depending on injection rate and analysis method used. Results from the cross-hole tests monitor intervals showed no significant correlation between permeability and injection rate; however, results from the injection interval showed a significant correlation between injection rate and permeability. Porosity estimates from the cross-hole testing range from 0.8 to
\end{abstract} 2.0 percent.

The maximum temperature change associated with the pneumatic testing was $1.2^{\circ} \mathrm{C}$ measured in the injection interval during cross-hole testing. The maximum temperature change in the guard and monitor intervals was $0.1^{\circ} \mathrm{C}$. The maximum error introduced into the permeability values due to temperature fluctuations is approximately 4 percent. Data from temperature monitoring in the borehole indicated a positive correlation between the temperature decrease in the injection interval during recovery testing and the gasinjection rate.

The thermocouple psychrometers indicated that water vapor was condensing in the boreholes during testing. The psychrometers in the guard and monitor intervals detected the drier injected gas as an increase in the dry bulb reading. The relative humidity in the test intervals was always higher than the upper measurement limit of the psychrometers. Although the installation of the packer system may have altered the water balance of the borehole, the gas-injection testing resulted in minimal or no changes in the borehole relative humidity.

\section{INTRODUCTION}

The U.S. Geological Survey (USGS) is forming a hydrologic characterization of the U.S. Department of Energy's potential high-level nuclear waste repository at Yucca Mountain, Nevada. The potential repository is located above the water table in a thick sequence of unsaturated volcanic-ash deposits called tuffs. Because the potential repository is in unsaturated tuff, several of the USGS site-characterization studies require measurement of in-situ gas-permeability values. This need required the development of downhole equipment and test methods for conducting in-situ pneumatic testing.

In 1987, the USGS began the design, construction, and testing of prototype gas-injection equipment that could be used at Yucca Mountain to estimate insitu gas-permeability values. This prototype development and testing provided the instruments, methods, and field experience needed to successfully conduct pneumatic testing at Yucca Mountain. The prototype testing was conducted at the University of Arizona's Apache Leap Tuff site located near Superior, Arizona. The site was selected because the rock is similar to that at Yucca Mountain.

Determination of the in-situ gas permeability in the unsaturated zone is analogous to solving the inverse problem in well hydraulics, but is complicated by gas compressibility, the Klinkenberg (1941) effect, temperature changes, and its effect on density and viscosity, and the possibility of altering the in-situ permeability by inducing water movement, or drying, or both. The determination is further complicated by the dual porosity system of fracture and matrix that exists in the welded tuffs at Yucca Mountain.

Because the in-situ gas permeability is dependent on the rock water content, and its associated capillary pressure, there is concern that the gas injection may result in moisture redistribution by forcing water 
out of fractures and pores or by removal of water through evaporation. If the capillary pressure is known, the gas-injection pressures can be limited to less than the capillary pressure, thereby, eliminating the possibility of forcing water out of fractures or pores. Limiting the injection pressures also minimizes gasexpansion temperature decreases and its effect on gas density and viscosity. To evaluate if the testing has altered the in-situ gas permeability, it is necessary to vary the injection pressures by conducting multiple tests at different gas-flow rates. If the different flow rates result in different calculated permeability values, there is a possibility that the in-situ moisture distribution has been altered.

The present conceptual hydrologic flow model of Yucca Mountain assumes that the maximum potential for gas flow is in the fractures (Montazer and Wilson, 1984). Because the fracture apertures are larger than the matrix pore diameters, capillary forces cause the fractures to dry first and remain dry during all but the wettest conditions. The water that is present will be in the matrix, therefore, the matrix will have a low pneumatic conductivity, and fractures will dominate the gas-flow system in Yucca Mountain. This situation may change under wetter climatic conditions. When fractures would be expected to dominate water transport in Yucca Mountain, estimates of dry fracture permeability can provide an estimate of saturated hydraulic conductivity, which is needed to evaluate the potential repository site.

\section{Purpose and Scope}

This report describes the results of prototype single-hole and cross-hole pneumatic testing of fractured and nonfractured ash-flow tuff at the University of Arizona's Apache Leap Tuff site near Superior, Arizona. The results of single-hole and cross-hole pneumatic testing at different flow rates are compared. The effect of humidified air and dry-nitrogen injection on the temperatures and relative humidity values in the test and monitoring intervals are presented. Data obtained from pneumatic testing with downhole pneumatic packers allow calculation of effective permeability and porosity values of finite test zones in the rock. Testing was conducted during December 1990 and May 1991, in two 30-m-long, 10-cm-diameter boreholes (X2 and Y2) drilled 45 degrees below horizontal. The test boreholes are parallel and $5 \mathrm{~m}$ apart. Boreholes X2 and $\mathrm{Y} 2$ are part of a group of nine boreholes drilled and used by the University of Arizona to conduct unsaturated zone hydraulic tests. The area around the boreholes is cov- ered with a $40-\mathrm{m}$ by $40-\mathrm{m}$ plastic cover to prevent infiltration of precipitation.

\section{Location of Study Area}

The Apache Leap Tuff site is located in southcentral Arizona, about $130 \mathrm{~km}$ east of Phoenix and $3 \mathrm{~km}$ east-northeast of Superior, Arizona (fig. 1). The site is located within the Tonto National Forest in Pinal County.

\section{Climate}

The site receives an average annual precipitation of about $640 \mathrm{~mm}$. The precipitation occurs during two periods, mid-July to late September when short duration summer thunderstorms are common, and midNovember to late March when long duration winter storms occur (Rasmussen and others, 1989). The mean-maximum temperature during July is $37^{\circ} \mathrm{C}$ and the mean-minimum temperature during January is $0^{\circ} \mathrm{C}$ (U.S. Department of Commerce Weather Bureau, 1959).

\section{Physiography}

The area surrounding the site is characterized by steep hills, narrow canyons and gullies, and steep ridges. The site is located at the southwestern boundary of the Mountain physiographic region of Arizona, as defined by Ransome (1903, p. 15); however, the geologic structural features are more closely related to the Basin and Range Province (Hammer and Peterson, 1968). The site is located on the Apache Leap Escarpment, which rises about $400 \mathrm{~m}$ above the town of Superior, Arizona, located $3 \mathrm{~km}$ to the east. The Apache Leap Escarpment is the upper rim of a volcanic plateau that extends eastward about $9 \mathrm{~km}$. The site altitude is $1,256 \mathrm{~m}$ above sea level. The vegetation is high-desert juniper and scrub-oak forest. The surface rock is rugged, unevenly weathered ash-flow tuff. The immediate area is extensively eroded by numerous ancient and modern stream channels that dissect the area. Soils are aridisols, thin and low in organic matter; much of the area is exposed bedrock. 

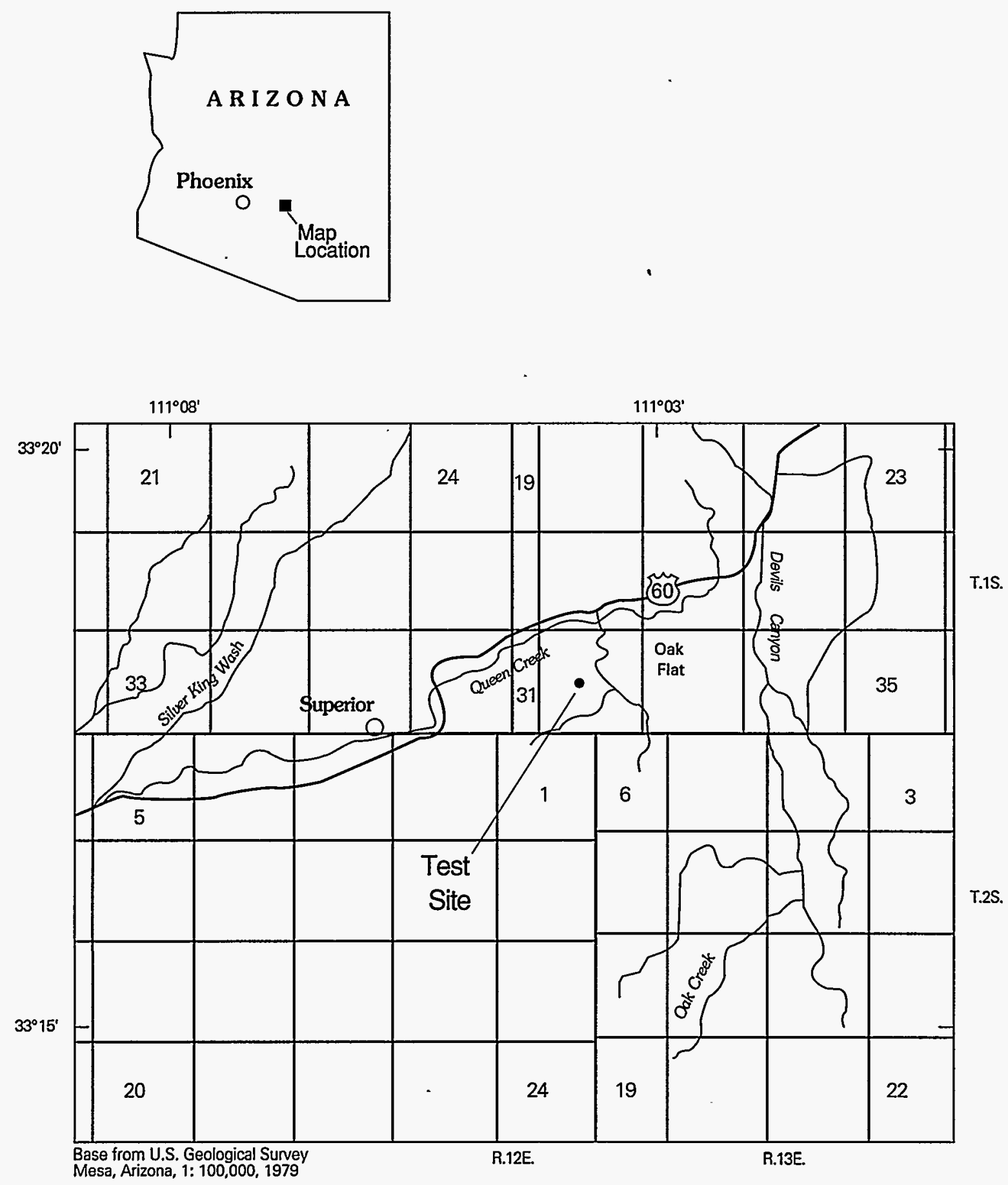

Flgure 1. Location of test site near Superior, Arizona. 


\section{Acknowledgments}

The author appreciates the cooperation of the University of Arizona for allowing the use of their Apache Leap Tuff site.

\section{GEOLOGIC SETTING}

The Apache Leap Tuff site is located on the remnants of an ash-flow sheet of Miocene age that overlies faulted limestone of Paleozoic age. These limestones contain Mesozoic intrusions that formed rich mineral deposits, most notably copper, that have been mined since 1875. The ash-flow sheet is composed of multiple ash flows that were erupted and deposited in such rapid succession that they formed a single cooling unit; therefore, the ash-flow tuffs are variably welded. The upper tuff is nonwelded and grades to a partly welded middle zone and densely welded lower zone. The thickness of the ash-flow sheet ranges from 300 to $600 \mathrm{~m}$ in the area of the site (Peterson, 1968). The test holes penetrate a zone of partly welded tuff.

The Superior area has two principal sets of faults (Hammer and Peterson, 1968). One set trends eastward, has a high degree of mineralization, and is mostly pre-Tertiary in age. A second, younger, nonmineralized set trends north to northwest and displaces the older eastward-trending faults. The test site is highly fractured by numerous, near-vertical joints. The dominate strike of the joints trends east by northeast; however, the jointing forms a distinct pattern with two principal systems that intersect at angles of 60 to 90 degrees. The joints range from clearly defined to indistinct, and most are spaced from 1.5 to $4.6 \mathrm{~m}$ (Peterson, 1962).

\section{TEST EQUIPMENT}

Testing was conducted using two pneumatic packer assemblies, each consisting of four sliding-end, inflatable packers connected by three hollow, steel pipes. The connecting pipes were ported so air, or other gases, could flow unobstructed into the borehole. When the packers were inflated, the borehole intervals between the inflated packers became isolated test intervals. The packers are identified as 1,2,3, and 4; packer number 1 being nearest the surface (fig. 2). Each packer had a dedicated inflation line that allowed test intervals of different lengths to be isolated. The packer assemblies were lowered into the boreholes with steel connecting rods. During injection testing, air or nitrogen was injected downhole through a 1.9-cm outsidediameter plastic tube. The tube opened into the central interval of one of the packer assemblies; this assembly is called the injection assembly, and the central interval is called the injection interval (I2). The intervals above and below the injection interval are called the upper guard interval (I1) and lower guard interval (13). During cross-hole testing, a second packer assembly was lowered into a nearby borehole. The second assembly is called the monitoring assembly, and the three test intervals were called monitor intervals, M1, M2, and M3 (fig. 3).

The guard, injection, and monitor intervals each contained one instrument bundle. The instrument bundles used in the guard and monitor intervals contained one pressure transducer, one thermistor, and one thermocouple psychrometer. The instrument bundle used in the injection interval contained one pressure transducer and one thermistor. The injection interval did not have a thermocouple psychrometer because the flowing injection air would render it inoperable. Each individual instrument bundle was connected to the surface by a dedicated electrical cable.

Pressure transducers provided absolute pressure values that were used in pneumatic test analysis for estimating permeability and porosity. The pressure transducers were standard four-wire variableresistance units. They measured absolute pressure with an accuracy of 0.1 percent of full scale. The pressure transducer range varied with the test interval: injection interval, $500 \mathrm{kPa}$ (kilopascals); guard intervals, $300 \mathrm{kPa}$; and monitor intervals, $150 \mathrm{kPa}$. The units were powered continuously with a constant voltage source supplying 10.0 volts. The output voltages $(0$ to 100 millivolts) were measured and stored by a programmable voltmeter/data logger located at the surface.

Thermistors were used to measure temperature and evaluate the isothermal assumptions used in the permeability calculations. The thermistors were $10,000 \mathrm{ohm}$ units with a waterproof plastic cover. High-resistance thermistors were selected to minimize the effect of long cable lengths. The units were operated in a four-wire configuration and powered with 10 microamps (maximum 1.0 volts) provided by a constant current source. To eliminate potential selfheating problems, the thermistors were powered for only 0.2 second with a sampling rate that did not exceed twice per minute.

The output voltage from the thermistors $(0$ to 150 millivolts) was measured and stored by a programmable voltmeter/data logger located at the surface. The thermistors were factory calibrated at 0,25 , and $40^{\circ} \mathrm{C}$. The calibration data were used to define the variables for the Steinhart and Hart equation (1968) which, along with the voltage output, was used to calculate the downhole temperatures. The four-wire configuration provided an outer power circuit to provide constant 


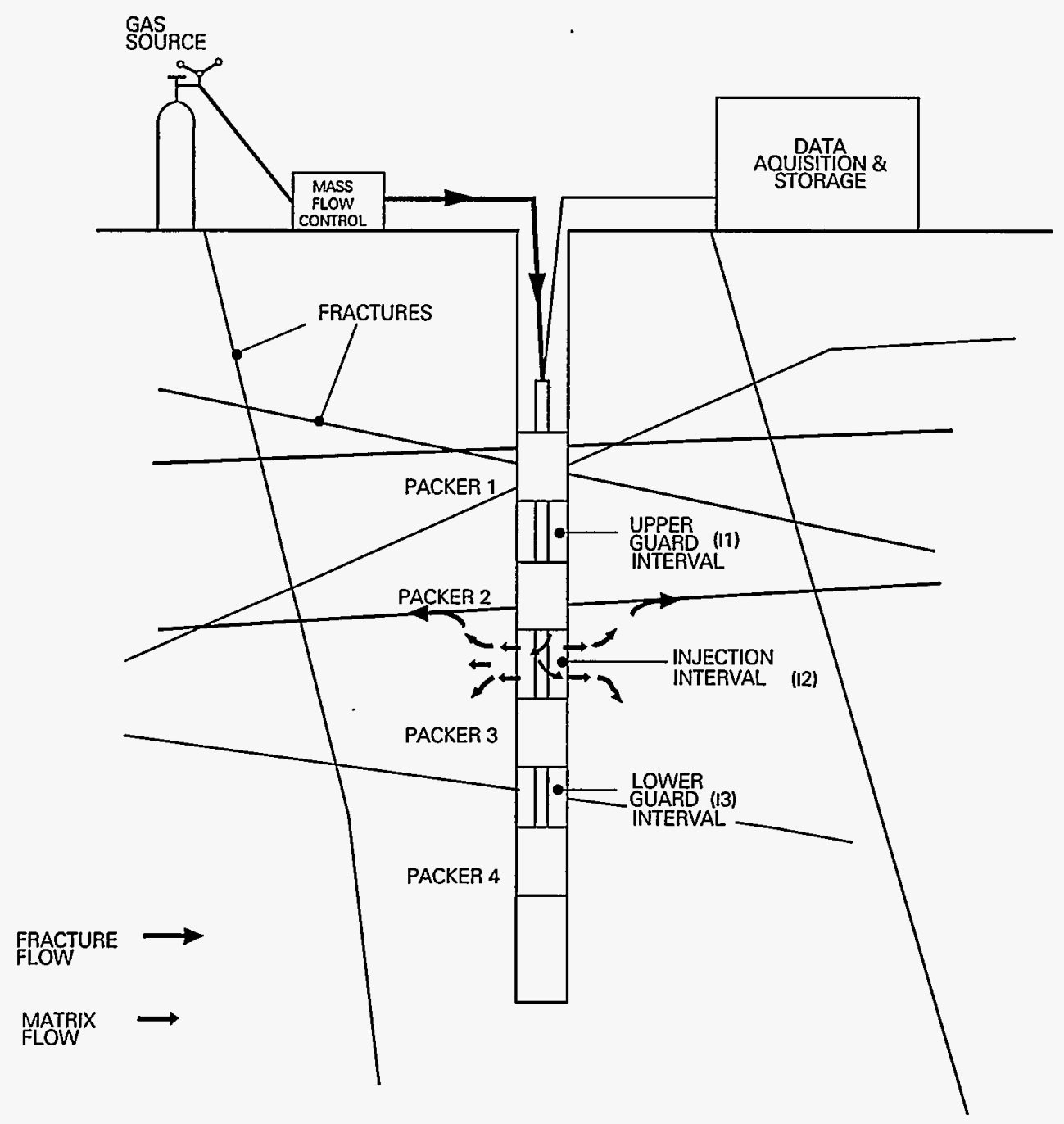

Figure 2. Schematic of single-hole gas-injection testing using a 4-packer packer assembly. 


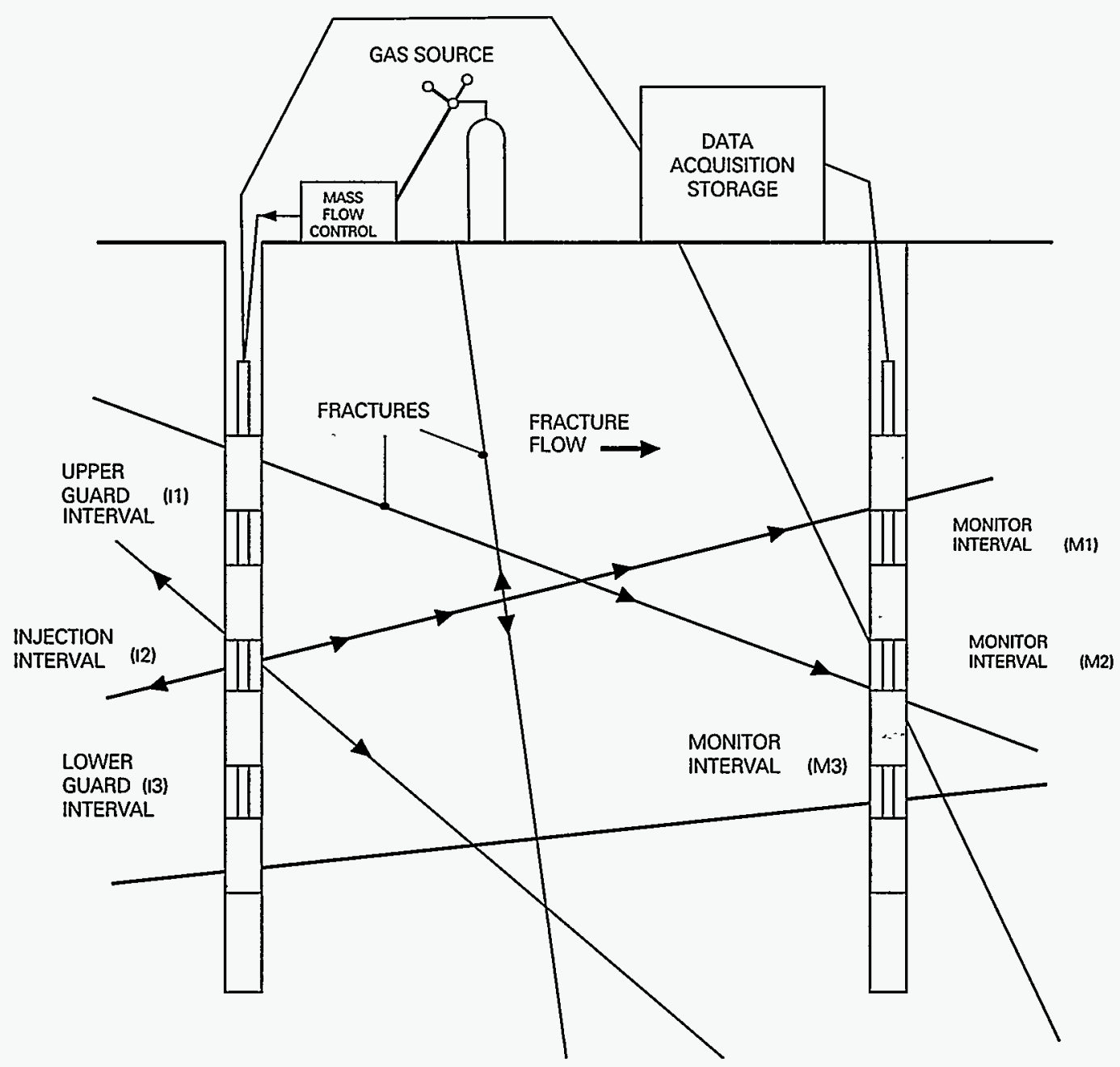

Figure 3. Schematic of cross-hole gas-injection testing using two 4-packer packer assemblies. 
current to the thermistor, and a high-impedance inner sensor circuit to measure the voltage output. The combination of high impedance, because of the data logger, and low current in the sensor circuit decreases the potential voltage drop associated with long wires. This configuration decreased the potential voltage drop error to less than that required to meet the desired $0.1^{\circ} \mathrm{C}$ sensitivity and $0.2^{\circ} \mathrm{C}$ accuracy. Downhole temperatures are required to interpret the pneumatic test results and to evaluate the assumption of an isothermal system. Questions concerning temperature changes associated with the expansion of the injected gas needed to be answered.

Another instrumentation goal of the prototype testing was to test the feasibility of using thermocouple psychrometers in the air-permeability testing program. It was hoped that the thermocouple psychrometer could measure relative humidity in the monitor and guard intervals. These relative humidity values could then be used to estimate the rock capillary pressure and to monitor any change that might be caused by pneumatic testing. Because the measured pneumatic permeability values of the rock are dependent on the air-filled pore space, any wetting or drying of the rock has the potential to change the permeability value. The thermocouple psychrometer were three-wire units, but due to wiring constraints, were operated as two-wire units. Operation of the units consisted of:

1. 15 seconds of 4.8 milliamperes heating current (to eliminate residual moisture) followed by,

2. 15 seconds of no current (to allow equilibration) followed by,

3. 30 seconds of 4.8 milliamperes cooling current followed by,

4. 30 measurements, at 1 second intervals.

The output of the thermocouple psychrometer ranged from -14 to 36 microvolts. Because of the long electrical cables and the associated potential voltage drop, the units were calibrated with the full cable lengths. The units were calibrated with $0.2,0.7$, and 1.5 molar $\mathrm{NaCl}$ and water solutions corresponding to potentials ranging from -884 to $-7134 \mathrm{kPa}$. During field testing, the thermocouple psychrometers were operated once every hour. The units were operated, measured, and the data stored with a programmable voltmeter/data logger located at the surface.

Support equipment consisted of: one portable computer, two data loggers, one constant-voltage power supply, one constant-current power supply, and a selection of mass-flow controllers ranging from 1 to 500 standard liters per minute (slpm). The portable computer was used to program sampling frequencies and to download data from the data loggers. The data loggers recorded the voltage output from the pressure transducers, thermistors, thermocouple psychrometer, and mass-flow controllers. The constant-voltage power supply powered the pressure transducers and the constant-current source powered the thermistors. The thermocouple psychrometers were operated by a dedicated data logger. The mass-flow controllers provided a constant gas-flow rate to the injection interval during gas-injection testing.

Additional support equipment included a 120 -volt AC generator, a compressor and gas saturator (for supplying high humidity-compressed air), and nitrogen tanks for supplying dry-compressed nitrogen. The gas saturator consisted of a 76-liter pressure vessel filled with a standing column of water through which the compressed air was bubbled. The purpose was to increase the humidity of the injected air and prevent insitu drying of the tuff.

\section{PNEUMATIC TEST METHODS}

\section{Single-Hole Gas-Injection Testing}

Single-hole pneumatic testing was limited to gas-injection testing in borehole $\mathrm{Y}-2$ using only the injection assembly. The purpose of the tests was to quantify temperature changes associated with gas expansion and to determine if the resulting permeability values calculated for the nonfractured tuff are dependent on the gas-injection rate or on the type of gas used.

The injection interval was in a nonfractured zone, $3.14 \mathrm{~m}$ in length, located at 7.2 to $10.34 \mathrm{~m}$ downhole from ground surface. This interval was isolated by inflating packers 1,3 , and 4 , to $1050 \mathrm{kPa}$. Packer number 2 was not inflated. The 3.14-m test-interval length was selected based on earlier testing conducted by the University of Arizona. A 3.14-m test interval was large enough to provide sufficient gas-flow rates to ensure the accuracy of the mass flow controllers.

Following inflation, the test intervals were allowed to stabilize until the pressure increase caused by the packer inflation had dissipated. Once the test interval had returned to atmospheric pressure, a constant flow rate of saturated air or dry nitrogen was injected into the test interval. Output from the pressure transducer, thermistor, and thermocouple psychrometer was monitored and recorded. Because packer 2 was not inflated, both the injection interval instrument bundle and the upper guard interval instrument bundle were located in the injection interval. Gas injection 
continued until the injection-interval pressure stabilized; this required about four hours.

Following injection testing, the packers were defiated and the borehole allowed to equilibrate overnight. No recovery tests were conducted because the low matrix permeability necessitated deflating the packers between tests to allow the pneumatic pressure buildup in the matrix to equilibrate. A total of seven single-hole gas-injection tests were conducted. Humidified air and dry nitrogen gas were injected at flow rates of 1.0, 3.0, 5.0, and 8.0 slpm. Pressure increases in the injection interval were limited to a maximum of $143.1 \mathrm{kPa}$ gauge pressure.

The single-hole testing was conducted for one week in December 1990. The first 2 days were warm and had high temperatures of $19^{\circ} \mathrm{C}$ and lows above freezing. The weather became progressively cooler as testing continued, and highs decreased to about $10^{\circ} \mathrm{C}$ and nighttime temperatures dropped to below freezing.

\section{Cross-Hole Gas-Injection and Recovery Testing}

The cross-hole pneumatic testing included both gas-injection and recovery testing between boreholes Y2 and X2. The purpose was to quantify the temperature change associated with gas expansion and to determine if the permeability and porosity values calculated from cross-hole testing in fractured rock were dependent on the injection rate, and if the injection and recovery testing values differed.

The injection assembly was installed in borehole $\mathrm{Y} 2$ and all four packers were inflated, isolating two 1.3 -m guard intervals ( 10.8 to 12.1 , and 17.7 to 19.0 meters below ground surface) and a $1.3-\mathrm{m}$ injection interval (15.8 to 17.1 meters below ground surface). The monitor assembly was installed in borehole $\mathrm{X} 2$ and packers 1, 2 and 3 were inflated, isolating two 1.3-m monitor intervals (14.6 to 15.9 and 16.5 to 17.7 meters below ground surface). Packer number 4 failed to inflate and, therefore, the third monitor interval extended from the bottom of packer 3 to the bottom of the borehole (18.4 to 30.5 meters below ground surface). The injection interval was located over a large fracture zone, and the monitor intervals were located in what was assumed to be the same fracture zone. Distances from the center of the injection interval to the center of monitor intervals M1 and M2 were 5.13 and $5.04 \mathrm{~m}$.

Following packer inflation, the intervals were allowed to equilibrate to atmospheric pressure. Following equilibration, compressed air was injected into the injection interval. The large gas volumes required for testing fractured tuff made it impractical to use nitrogen as an injection gas, therefore, only compressed air was injected. The air was not humidified. During testing, the pressure response, temperature, and relative humidity were monitored in all intervals. The test was conducted until the pressure response in the monitor intervals had stabilized, which required 2 to 4 hours.

After each cross-hole gas-injection test was complete, the air flow was halted, and the recovery period was monitored. Recovery tests were run until all intervals had returned to atmospheric pressure. A total of six gas-injection tests and five recovery tests were conducted. Testing was terminated after the sixth injection test. Injection flow rates ranged from 12.7 to $98.7 \mathrm{slpm}$. Pressure increases in the injection interval were limited to a maximum of $160.5 \mathrm{Kpa}$ gauge pressure.

The cross-hole pneumatic testing was conducted for 1 week during May 1991. The weather was sunny and clear and temperatures ranged from $10^{\circ} \mathrm{C}$ at night to as much as $30^{\circ} \mathrm{C}$ in the daytime.

\section{PNEUMATIC TEST ANALYSIS}

The analysis methods and models that were used in analyzing the pneumatic testing were originally developed for incompressible fluids. Modification of these methods to deal with compressible fluids and model geometry requires the following assumptions.

1. The ideal gas law applies and, therefore, the compressibility of the gas is inversely related to the pressure,

$$
c=\frac{1}{P}
$$

where,

$$
c=\text { compressibility, in Pascals }{ }^{-1} \text {; }
$$$$
P=\text { pressure, in Pascals. }
$$

2. The system is isothermal and, therefore, the gas density and viscosity, which are both temperature dependent, remain constant. The effect of temperature change on the gas density can be evaluated by equation 2 (Weast 1987),

$$
\rho=\rho_{s c}\left(\frac{T_{s c}}{T}\right)
$$

where,

$\rho$. = gas density, in kilograms per cubic meter;

$\rho_{s c}=$ gas density at standard conditions, in kilograms per cubic meter;

$T s c=$ temperature at standard conditions, in degrees Kelvin; and

$T$ = temperature, in degrees Kelvin. 
An approximate effect of temperature change on gas viscosity can be evaluated by equation 3 (Noggle, 1985),

$$
\mu=\mu_{s c}\left(\frac{\sqrt{T}}{\sqrt{T_{s c}}}\right)
$$

$\mu=$ dynamic viscosity, in Pascal seconds;

$\mu_{s c}=$ dynamic viscosity at standard conditions, in Pascal seconds.

To deal with the assumption that the system is isothermal, injection pressures were limited to minimize temperature changes caused by gas expansion, and thermistors were installed to monitor any temperature changes.

3. Gravitational effects can be excluded. This is reasonable because the increased pressure from the weight of the higher density gas is small compared to the gas injection pressure.

4. Flow is laminar. This assumption deals with turbulence, inertial, and Klinkenberg effects. Use of low injection pressures minimizes the potential for turbulent flow in the fractures, and inertial forces in the matrix. However, if the flow paths are limited, for example, if all flow in what was thought to be a highly fractured test interval was actually limited to a single fracture, there is potential for turbulent flow. Turbulent flow conditions during testing can result in the higher flow-rate tests indicating lower permeability values than the lower flow-rate tests. Inertial forces will have the same effect on matrix flow. The Klinkenberg effect states that in finegrained materials at low pressures, slippage of molecules occurs. This is expressed mathematically as,

$$
k=k_{h}\left(1+\frac{b}{P}\right)
$$

where,

$$
\begin{aligned}
k= & \text { effective permeability, in square meters; } \\
k_{h}= & \text { high pressure permeability, in square } \\
& \text { meters; and } \\
b \quad= & \text { parameter of media, in Pascal. }
\end{aligned}
$$

The permeability value where the Klinkenberg effect becomes noticeable is variable but, as a general rule, usually less than $10^{-14} \mathrm{~m}^{2}$ (Weeks, 1977). This means it is generally not a factor in the higher permeabilityfracture flow systems, but may become a factor in testing of the less permeable matrix. The Klinkenberg effect can result in the lower injection-rate tests indicating larger permeability values than the higher flowrate tests. Concerns about turbulent flow, inertial influences, and the Klinkenberg effect are addressed by testing at different flow rates; the different tests should result in similar permeability values.

5. The medium is homogeneous, isotropic, and incompressible. The homogeneous and isotropic assumptions are questionable in most test situations, but are even more suspect when testing in fractured rock. Fractures, by definition, are not isotropic, and the fact that fractures are present in a low-permeability matrix, means that the rock is not homogeneous. The rationale used to justify these assumptions deals with the scale of testing and the REV (representative elementary volume). In the simplest terms, the REV is the minimum sample size at which the rock behaves as an equivalent pores medium. Testing at a scale smaller than the REV voids these assumptions and results in a large variance between tests. Tests conducted at a scale larger than the REV may result in the loss of information on the variability that exists in even the most consistent rock formations. The testing goal was to select a test scale that matches the REV for the Apache Leap Test site, and therefore, allows the assumptions. In a fractured system, this means the test interval must intercept enough fractures so that the flow system behaves as an equivalent pores medium.

Because the air permeability of a rock changes with water content, a given permeability also has an associated capillary pressure. Capillary pressure is the pressure difference across the interface between the gas and liquid phases. Capillary pressure increases when this interface is confined to smaller pores or fractures and decreases as this interface moves to larger pores or fractures. The larger pores and fractures are potentially the most conductive features and are dry at all but the wettest conditions (lowest capillary pressures). Using the capillary equation,

$$
P=\frac{2 \gamma}{r}
$$

where,

$$
\begin{aligned}
& P=\text { pressure }\left(\mathrm{N} / \mathrm{m}^{2}\right) ; \\
& \gamma=\text { surface tension of water }(\mathrm{N} / \mathrm{m}) ; \text { and } \\
& r \quad=\text { radius of tube }(\mathrm{m}),
\end{aligned}
$$

it is possible to approximate the size of the pores and fractures that will be dry at a given capillary pressure. For example, if the steady-state test differential pressure is $101.3 \mathrm{Kpa}$, then the associated pore diameter is 
$2.8 \mu \mathrm{m}$ (microns). This means that pores with a diameter larger than $2.8 \mu \mathrm{m}$, or fractures with apertures larger than $2.8 \mu \mathrm{m}$, lack the capillary force to retain water against the injection pressure, and therefore, the water will be forced out of these pores and fractures. This has potential of altering the water content, and therefore, the permeability is additional rationale for limiting injection pressures and for conducting multiple tests at different gas-injection rates.

\section{Steady-State Analysis}

Steady-state analysis was used to evaluate injection-interval (I2) data from the single-hole gas-

injection tests. The analysis uses a modified version of the Hvorslev (1951) solution for steady-state elliptical flow. Testing assumes that the pressure in the injection interval is at steady state, and the solution is modified. for compressible fluids. The original equation is expressed as,

$$
K=\frac{Q \ln \left(\frac{L}{r_{w}}\right)}{2 \pi \Delta H L}
$$

where,

$K=$ hydraulic conductivity, in meters per second;

$Q$ = flow rate, in cubic meters per second;

$L=$ length, in meters;

$r_{w}=$ well radius, in meters; and

$\Delta H=$ change in head, in meters.

The change in head and hydraulic conductivity can be redefined as,

$$
\begin{gathered}
\Delta H=\frac{P_{2}-P_{1}}{\rho g} \\
K=\frac{k \rho g}{\mu}
\end{gathered}
$$

where,

$P_{2}=$ final pressure, in Pascals;

$P_{I}=$ starting pressure, in Pascals;

$p=$ density, in kilograms per cubic meter;

$g=$ acceleration of gravity, in meters per second squared;

$k=$ permeability, in square meters; and

$\mu=$ dynamic viscosity, in Pascal seconds).
Volumetric flux in the formation can be expressed as,

$$
Q=\frac{2 \pi L\left(P_{2}-P_{1}\right) k}{\mu 1 n\left(\frac{L}{r_{w}}\right)} .
$$

The pneumatic testing program uses mass-flow controllers to control the mass-flow rate. Because mass flux is constant,

$$
\rho_{h} Q_{h}=\rho_{f} Q_{f}=\rho_{s c} Q_{s c}
$$

where the subscripts are,

$h=$ in the injection hose;

$f=$ in the formation; and

$s c=$ at standard conditions.

Pressure and temperature for an ideal gas are related by,

$$
\rho=\frac{P}{R T}
$$

where,

$$
\begin{aligned}
R= & \text { individual gas constant, in joules per } \\
& \text { kilogram degrees Kelvin; and } \\
T= & \text { temperature, in degrees Kelvin. }
\end{aligned}
$$

therefore, assuming constant temperature,

$$
P_{h} Q_{h}=P_{f} Q_{f}=P_{s c} Q_{s c} .
$$

Assuming the average formation pressure is,

$$
P_{f}=\frac{\left(P_{2}+P_{1}\right)}{2}
$$

and the average flow volume in the formation is given by equation 9 , then equations 9,12 , and 13 can be combined to yield,

$$
P_{h} Q_{h}=P_{s c} Q_{s c}=\frac{P_{2}+P_{1}}{2} \frac{2 \pi L\left(P_{2}-P_{1}\right) k}{\mu 1 n\left(\frac{L}{r_{w}}\right)}
$$

and correcting the gas volume for temperature yields,

$$
k=\frac{P_{s c} Q_{s c} \mu 1 n\left(\frac{L}{r_{w}}\right) T_{f}}{\pi L\left(P_{2}^{2}-P_{1}^{2}\right) T_{s c}}
$$




\section{Semilog Analysis}

Semilog analysis was used to evaluate the injection-interval (I2) data from the single-hole and crosshole gas-injection and recovery tests. The analysis uses a modified version of the Cooper and Jacob (1946) straight-line radial-flow solution for homogeneous isotropic systems. The solution is modified for compressible fluids by use of the pressure-squared differences (Energy Resources Conservation Board, 1975). The solution states that when the radius is small or time is large, or both, the dimensionless pressure change can be represented as,

$$
\Delta P_{D}=\frac{1}{2}\left(\ln \left(\frac{t_{D}}{r_{D}^{2}}\right)+0.809\right)
$$

where,

$$
\begin{gathered}
r_{D}=\frac{r}{r_{w}} \\
\Delta P_{D}=\frac{\left(P^{2}-P_{i}^{2}\right)}{P_{i}^{2} q_{D}} \\
q_{D}=\frac{P_{s c} Z T q_{s c} \mu}{\pi k h P_{i}^{2} T_{s c}} \\
t_{D}=\frac{k t}{\phi \mu \bar{c} r_{w}^{2}}
\end{gathered}
$$

and,

$$
\begin{aligned}
& P_{D}=\text { dimensionless pressure; } \\
& t_{D}=\text { dimensionless time; } \\
& r_{D}=\text { dimensionless radius; } \\
& r_{W}=\text { well radius, in meters; } \\
& r=\text { radius, in meters; } \\
& P_{i}=\text { initial pressure, in Pascals; } \\
& P=\text { pressure, in Pascals; } \\
& q_{D}=\text { dimensionless flow; } \\
& P_{s c}=\text { pressure at standard conditions, in Pascals; } \\
& Z=\text { gas constant, dimensionless; } \\
& T=\text { temperature, in degrees Kelvin; } \\
& q_{s c}=\text { gas flow at standard conditions, in cubic } \\
& \mu \quad \text { meters per second; } \\
& \mu=\text { gas dynamic viscosity, in Pascal } \\
& k \quad \text { seconds; } \\
& k=\text { effective permeability, in meters squared; } \\
& h=\text { formation thickness, in meters; } \\
& T_{s c}=\text { temperature at standard conditions, in }
\end{aligned}
$$

$$
\begin{aligned}
& \text { degrees Kelvin; } \\
t \quad= & \text { time, in seconds; } \\
\phi \quad= & \text { porosity, in cubic meter per cubic meter; and } \\
c \quad= & \text { average gas compressibility, in } \text { Pascal }^{-1} \text {. }
\end{aligned}
$$

Using the five assumptions, the equations simplify to,

$$
\left(P^{2}-P_{i}^{2}\right)=\frac{2.3}{2 \pi} \frac{P_{s c} T q_{s c} \mu}{T_{s c} h k}\left(\log \left(\frac{k \grave{t} P}{\phi \mu r_{w}^{2}}\right)+0.352\right)
$$

Equation 20 defines a solution that has a slope of $m$ where,

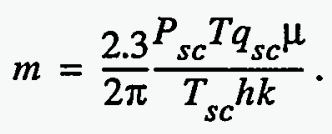

Because the semilog plot of the pressure-squared differences with the log of time is linear, the effective permeability can be calculated by,

$$
k=\frac{0.366 P_{s c} T q_{s c} \mu}{T_{s c} h m}
$$

where $m$ is the pressure-squared difference for one $\log$ cycle of the transient, straight-line flow period.

\section{Leaky Radial-Flow Type Curve Analysis}

The injection-interval (I2) data from the crosshole testing were analyzed using a modified radial-flow type-curve solution developed by Hantush and Jacob (1955) and expanded by Cooper (1963). The method assumes flow is radial but also considers leakage. The method was developed to account for the alteration of the radial-flow geometry by semi-impervious confining layers, but it may also apply to fracture-flow systems where the radial-flow geometry of a single fracture is altered by a permeable matrix or intersecting fractures. Hantush and Jacob defined a leakage component,

$$
\frac{r}{B}=r \sqrt{\frac{K^{\prime}}{K b b^{\prime}}}
$$

where,

$$
\begin{aligned}
K^{\prime}= & \text { hydraulic conductivity of confining layer, } \\
& \text { in meters per second; } \\
K \quad= & \text { hydraulic conductivity of aquifer, in meters } \\
& \text { per second; } \\
b \quad= & \text { thickness of aquifer, in meters; and } \\
b^{\prime}= & \text { thickness of confining layer, in meters. }
\end{aligned}
$$


Cooper defined the same component as,

$$
v=\frac{r}{2} \sqrt{\frac{K^{\prime}}{K b b^{\prime}}} .
$$

This new component was incorporated into the new type curve as,

$$
L(u, v)=\int \frac{\infty}{u} \frac{e^{-y-\frac{v^{2}}{y}}}{y} d y
$$

where,

$$
u=\frac{r_{D}^{2}}{4 t_{D}}
$$

and,

$$
y=\text { variable of integration. }
$$

The solution was redefined for use in this paper as,

$$
\Delta P_{D}=\frac{1}{2} L(u, v) \text {. }
$$

The log-log plot of the pressure-squared differences with time was matched with the log-log plot of the dimensionless pressure change with dimensionless time divided by the dimensionless radius squared. A match point then was used to calculate effective permeability by,

$$
k=\frac{\Delta P_{D} T_{f} q_{s c} P_{s c} \mu}{\left(P^{2}-P_{i}^{2}\right) h T_{s c} \pi}
$$

Because this flow model has an unknown number of fractures and unknown matrix permeability in place of the semipermeable confining bed, the values $K^{\prime}$ and $b^{\prime}$ don't have true values. However, the larger the number of connecting fractures and the greater the fracture and matrix permeability values, the larger the $v$ value.

\section{Spherical-Flow Type Curve Analysis}

Data from the cross-hole testing in monitor interval (M1, and $M 2)$ were analyzed using a spherical-flow type-curve solution. Carslaw and Jaeger (1959) intro- duced the use of the complimentary error function as a solution for heat flow in solids. The solution has been adapted for use in natural-gas reservoir and aquifer testing (Energy Resources Conservation Board, 1975). The method assumes that the pumping interval and monitoring intervals can be represented as points in a large homogeneous, isotropic system, and uses the pressure-squared differences. The solution defines the dimensionless pressure as,

$$
\Delta P_{D}=\frac{1}{2} \operatorname{erfc}\left(\frac{r_{D}^{2}}{4 t_{D}}\right)^{\frac{1}{2}}
$$

where,

$$
\operatorname{erfc}(z)=\frac{2}{\pi} \int_{z}^{\infty} e^{-t^{2}} \partial t=1-\left(\frac{2}{\pi} \sum_{n=0}^{\infty} \frac{(-1)^{n} z^{2 n+1}}{n !(2 n+1)}\right)
$$

Using the type-curve match points, the effective permeability is,

$$
k=\frac{T_{f} Q_{s c} \mu P_{s c} \Delta P_{D}}{\left(P_{i}^{2}-P_{o}^{2}\right) r \pi T_{s c}}
$$

and porosity is calculated by,

$$
\phi=\frac{k t \bar{P}}{\frac{t_{D}}{r_{D}} \mu r^{2}} .
$$

\section{THERMISTOR - RESULTS AND DISCUSSION}

\section{Single-Hole Testing Thermistor - Results and Discussion}

During the December 1990 single-hole testing, fluctuating temperatures measured by the two thermistors in the injection interval were compared with the stable, consistent temperatures measured in the lower guard interval. Results indicate that the thermistors have a sufficiently short response time and are sensitive to temperature changes of less than $0.1^{\circ} \mathrm{C}$. The absence of any measurable temperature drift indicates there were no problems with thermistor selfheating.

Pre-test temperatures measured by the three injection-string thermistors showed temperature 




Figure 4. Temperature in the injection interval during single-hole gas-injection test Test 6.

decreasing with depth at a gradient of $0.4^{\circ} \mathrm{C}$ per meter of vertical depth. Based on the shallow vertical-test depths, the pre-test temperature gradient was probably due to near-surface residual summer-heat storage. The temperature response in the injection interval during Test 6 is shown in figure 4; this was a typical temperature response observed during single-hole testing.

Temperature changes in the injection interval during the December 1990 single-hole gas-injection testing are listed in table 1. Also listed are the gas type, injection rate, and the maximum differential pressure. The injection interval pre-testing temperature was $21.5^{\circ} \mathrm{C}$, and the post-testing temperature was $21.4^{\circ} \mathrm{C}$. The maximum temperature change measured in the lower guard interval was $-0.1^{\circ} \mathrm{C}$ (During single-hole testing, the upper guard interval was part of the $3.14 \mathrm{~m}$ injection interval). The maximum temperature change measured was $-0.4^{\circ} \mathrm{C}$. The correlation coefficients between the gas-injection rate and the temperature change are: for all gas-injection tests, -0.74 ; for nitrogen-injection tests, -0.77 ; and for air-injection tests, -0.65 . The correlations coefficients are all negative because the gas expansion resulted in a decrease in the injection-interval temperature. The greater the flow rate and associated pressure increase, the greater the temperature drop.

Table 1. Temperature changes in the injection interval during December 1990 single-hole gas-injection testing

\begin{tabular}{|c|c|c|c|c|}
\hline $\begin{array}{c}\text { Test } \\
\text { name }\end{array}$ & $\begin{array}{c}\text { Temperature } \\
\text { change } \\
\left({ }^{\circ} \mathrm{C}\right)\end{array}$ & $\begin{array}{l}\text { Gas } \\
\text { type }\end{array}$ & $\begin{array}{c}\text { Injëction } \\
\text { rate } \\
(\operatorname{sipm})^{1}\end{array}$ & $\begin{array}{c}\text { Maximum } \\
\text { pressure } \\
\text { difference } \\
(\mathrm{kPa})^{2}\end{array}$ \\
\hline Test 1 & -0.1 & Air & 5.0 & 103.0 \\
\hline Test 2 & 0.1 & Air & 1.0 & 34.5 \\
\hline Test 3 & -0.2 & Air & 3.0 & 73.5 \\
\hline Test 4 & -0.0 & $\mathrm{~N}_{2}$ & 1.0 & 35.5 \\
\hline Test 5 & -0.2 & $\mathrm{~N}_{2}$ & 3.0 & 73.2 \\
\hline Test 6 & -0.4 & $\mathrm{~N}_{2}$ & 5.0 & 100.3 \\
\hline Test 7 & -0.3 & $\mathrm{~N}_{2}$ & 8.0 & 143.1 \\
\hline
\end{tabular}


Temperature changes measured in the downhole intervals were the result of both gas expansion and the temperature of the injection gas. Using equations 2 and 3 , and the $0.4^{\circ} \mathrm{C}$ maximum temperature change, the maximum effect of fluctuating temperature on the calculated permeability values is less than 2 percent. Considering the inherent potential for variability in the test methods and analysis, temperature changes had no adverse effects on the results of the single-hole pneumatic testing and analysis, for the injection ranges and associated pressure increases tested.

\section{Cross-Hole Testing Thermistor - Results and Discussion}

During the May 1991 cross-hole testing, fuctuating temperatures measured in the injection interval were compared with the stable, consistent temperatures measured in the guard and monitor intervals. Results indicate that the units have a sufficiently short response time and are sensitive to temperature changes of less than $0.1^{\circ} \mathrm{C}$. The absence of any measurable drift indicates there were no problems with thermistor selfheating.

Pre-test temperatures in the injection interval, the lower guard interval, and all three monitor intervals were $20.4^{\circ} \mathrm{C}$. Post-test temperatures were all plus-orminus $0.1^{\circ} \mathrm{C}$ of $20.4^{\circ} \mathrm{C}$. The thermistor in the upper guard interval was never operational. Temperature fluctuations in the injection interval during cross-hole test Inject 1, and its associated recovery test Recov 1, are presented in figure 5. Figure 5 is a typical temperature response observed during the cross-hole testing and consists of: 1) an early rapid temperature drop at the start of gas injection, 2) a stable period during gas injection, 3) a rapid temperature decline when gas injection was halted and, 4) a long-term temperature increase during the recovery period.

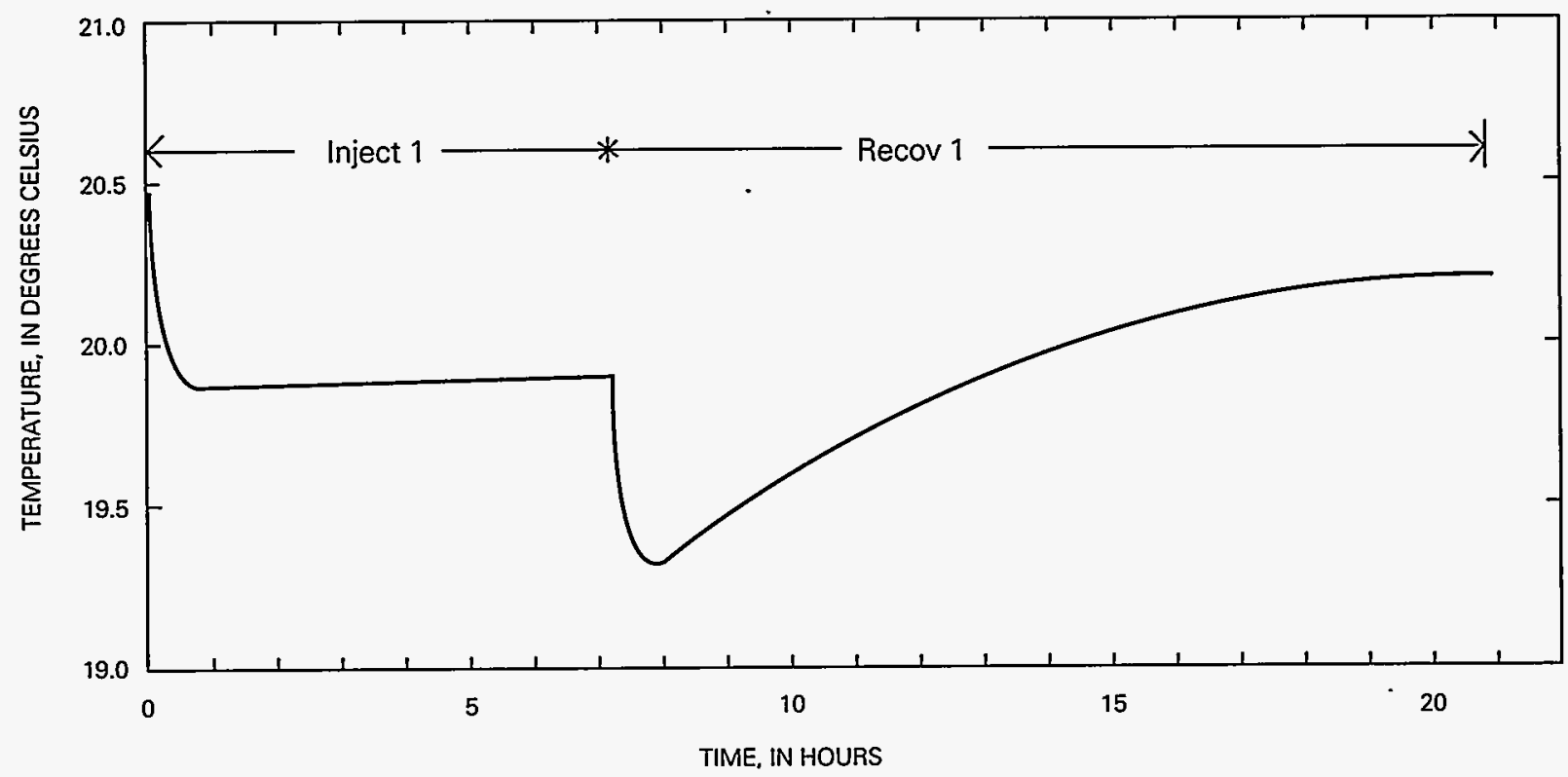

Figure 5. Temperature in the injection interval during cross-hole gas-injection and recovery tests Inject 1 and Recov 1. 
Table 2 summarizes the temperature changes, injection rates, and the maximum pressure differentials in the injection interval during the May 1991 crosshole gas-injection and recovery testing. The tests are numbered in order of testing but are arranged in order of increasing injection rate. The injection tests are designated "Inject," and the associated recovery tests are designated "Recov".

Table 2. Initial and long-term temperature changes in the injection interval during May 1991 cross-hole gas-injection and recovery testing

\begin{tabular}{|c|c|c|c|c|}
\hline \multirow{2}{*}{$\begin{array}{l}\text { Test } \\
\text { name }\end{array}$} & \multicolumn{2}{|c|}{$\begin{array}{l}\text { Temperature } \\
\text { change }\left({ }^{\circ} \mathrm{C}\right)\end{array}$} & \multirow{2}{*}{$\begin{array}{l}\text { Injection } \\
\text { rate } \\
\text { (sipm) }\end{array}$} & \multirow{2}{*}{$\begin{array}{l}\text { Maximum } \\
\text { pressure } \\
\text { difference } \\
\quad(\mathrm{kPa})\end{array}$} \\
\hline & $\begin{array}{l}\text { Initial' } \\
\text { period }\end{array}$ & $\begin{array}{l}\text { Long }^{2} \\
\text { term } \\
\text { period }\end{array}$ & & \\
\hline Inject 5 & -0.3 & -0.2 & 12.7 & 36.7 \\
\hline Recov 5 & -0.1 & 0.7 & - & 36.4 \\
\hline Inject 4 & -0.2 & -0.2 & unknown & 50.5 \\
\hline $\operatorname{Recov} 4$ & -0.3 & 0.8 & - & 50.8 \\
\hline Inject 2 & -0.3 & -0.3 & 23.6 & 62.7 \\
\hline $\operatorname{Recov} 2$ & -0.3 & 1.0 & - & 63.9 \\
\hline Inject 1 & -0.4 & -0.1 & 50.0 & 111.3 \\
\hline Recov 1 & -0.6 & 0.9 & - & 108.2 \\
\hline Inject 3 & -0.3 & 0.2 & 74.8 & 141.0 \\
\hline Recov 3 & $-0.8^{\circ}$ & 0.7 & - & 139.7 \\
\hline Inject $6^{3}$ & -0.3 & 0.5 & 98.6 & 160.5 \\
\hline \multicolumn{5}{|c|}{$\begin{array}{l}60 \text { minutes from the start and halt of gas flow, respectively. } \\
{ }^{2} \text { Long term is all time following the initial period. Injection test- } \\
\text { ing lasted as long as seven hours and recovery testing as long as }\end{array}$} \\
\hline
\end{tabular}

During the early test period, the injectioninterval thermistor had a rapid temperature change followed by a longer period of slower temperature change. Therefore, to better depict this, the injectioninterval temperature data in table 2 are separated into two periods. The initial period is defined as the first 30 and 60 minutes of the injection and recovery tests, respectively. The long-term period is all time following the initial period. The long-term period lasted up to 7 hours during injection testing and 16 hours during recovery testing.

The maximum temperature change in the injection interval during cross-hole testing was $1.2^{\circ} \mathrm{C}$. The maximum temperature fluctuations in the guard and monitor intervals were $0.1^{\circ} \mathrm{C}$. Following testing, the temperatures in all intervals were within $0.1^{\circ} \mathrm{C}$ of their pre-test temperatures. The lowest-injection interval temperature recorded was $19.3^{\circ} \mathrm{C}$, during the initial period of Recov 1 , and the highest $20.5^{\circ} \mathrm{C}$ at the end of Inject 6. During the initial period, all injection tests had temperature decreases of 0.2 to $0.4^{\circ} \mathrm{C}$ following the start of gas injection. This temperature decrease is independent of the injection rate. The recovery tests had initial-period temperature decreases of 0.1 to $0.8^{\circ} \mathrm{C}$ following the halting of gas flow. The correlation between the recovery-test initial-period temperature decrease and its associated injection rate was -0.99 .

Temperature changes measured in the downhole intervals were the result of both gas expansion and the temperature of the injection gas. The larger temperature changes measured were the result of gas expansion during the initial period of the recovery tests. Using the maximum temperature change measured, $1.2^{\circ} \mathrm{C}$, and equations 2 and 3 , the maximum effect of fluctuating temperature on the calculated permeability values is less than 4 percent. Considering the inherent potential for variability in the test methods and analysis, the temperature changes had no adverse effects on results of the cross-hole pneumatic testing and analysis, for the injection ranges and associated pressure increases tested.

\section{THERMOCOUPLE PSYCHROMETER - RESULTS AND DISCUSSION}

\section{Single-Hole Testing Thermocouple Psychrometer - Results and Discussion}

During the December 1990 single-hole testing, problems with the activation channel on the data logger resulted in no data from the thermocouple psychrometers.

\section{Cross-Hole Testing Thermocouple Psychrometer - Results and Discussion}

During the May 1991 cross-hole testing, four of the five thermocouple psychrometer were operational. Gas injection began about 30 minutes after the first thermocouple psychrometer readings were obtained. Relative humidity values in the injection, guard, and monitor intervals exceeded the range of the thermocouple psychrometer at all times during testing. Figure 6 shows the zero (dry-bulb) values for the May 1991 cross-hole testing; negative values indicate that the 


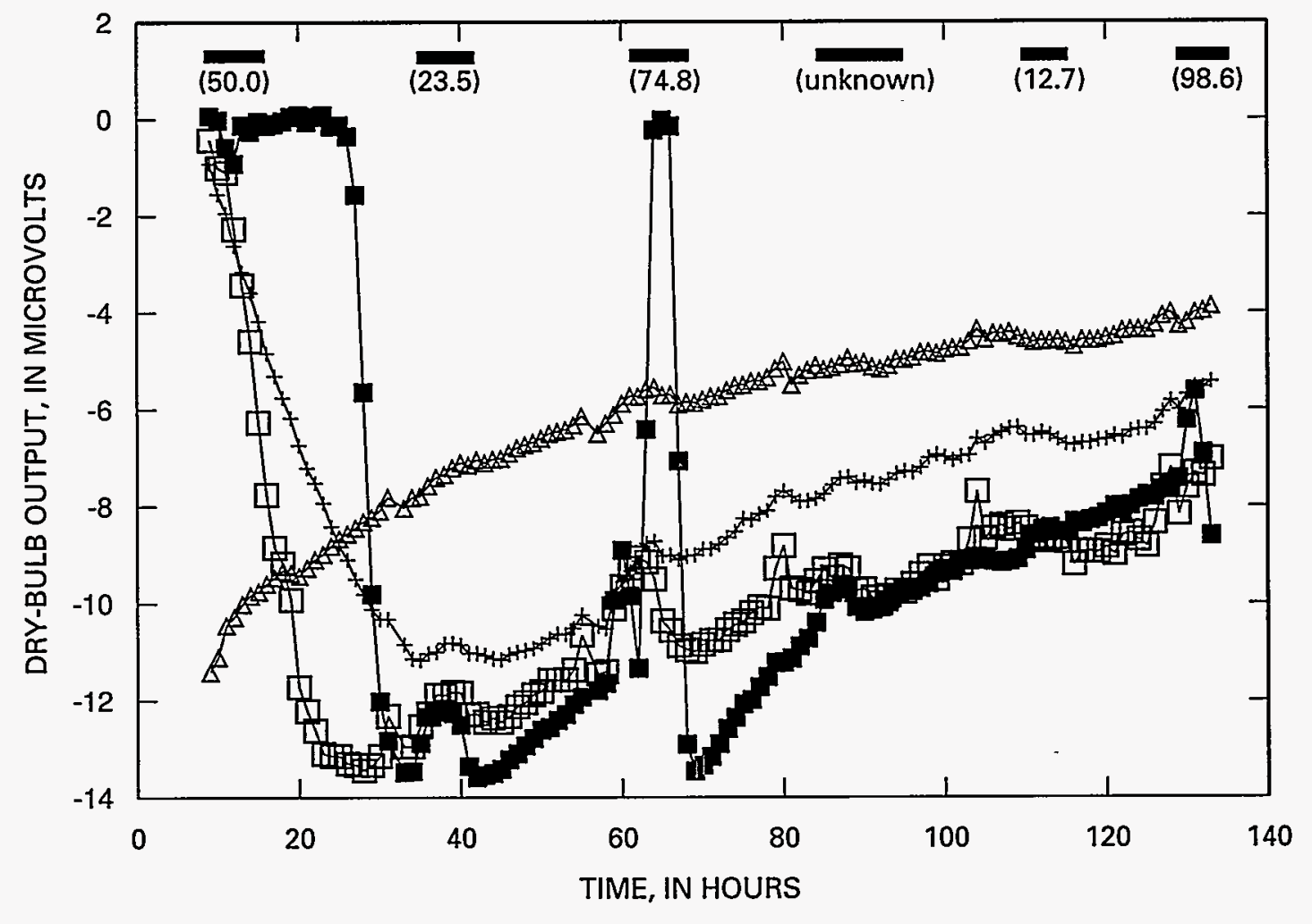

EXPLANATION

+ Monitor Interval $1 \quad$ (M1)

口 Monitor Interval 2 (M2)

$\Delta$ Monitor Interval $3 \quad$ (M3)

- Lower Guard Interval (I3)

- Gas-injection period

( ) Gas-injection rate, in standard liters per minute

Figure 6. Dry-bulb readings from thermocouple psychrometers during cross-hole gas-injection and recovery testing, May 1991. 
intervals were at saturation and that water vapor was condensing. The more negative the dry-bulb value, the greater the amount of condensation.

The initial dry-bulb values for three of the intervals, (I3, M1, M2) were near zero, but became more negative during the first 30 hours of testing and then gradually increased during the remaining test period (fig. 6). Guard interval I3 initially followed the pattern of $\mathrm{M} 1$ and $\mathrm{M} 2$ but soon deviated, possibly due to its location nearest the gas-injection interval. Initial voltage at monitor interval M3 was - 11.5 microvolts followed by a steady increase during the test period. Monitor interval M3 was the largest monitor interval as a result of the deflation of the monitor assembly packer 4 , and was located furthest from the injection interval. The data indicate that all the intervals were equilibrating during the testing period.

The equilibration trends shown in figure 6 indicate that the condensation decreased over the testing period. This may have been due to borehole equilibration following the installation of the packers. Installation of the packer system resulted in a pathway for the conduction of energy through the metal rods that connected the packer system to the ground surface. As expected, the intervals furthest from the gas-injection interval, M1 and M2, show the more stable equilibration curves.

The guard and monitor intervals showed a decrease in condensation during some of the airinjection tests. The decreased condensation was due to the addition of the dryer-injected air. Guard interval I3, located nearest the injection interval, had numerous fluctuations. During the 50 and $74.8 \mathrm{slpm}$ injection tests, the readings from $\mathrm{I} 3$ increased to zero; however, the relative humidity values during these periods were still greater than the range of the thermocouple psychrometers. In several instances, the recovery observed in $\mathrm{I} 3$ following the halting of gas injection was to a more negative level than before the gas was injected. The increased condensation was due to the decreased temperature associated with the gas expansion, in the formation and test intervals, during the recovery tests.

The high moisture content in the boreholes may be due to the plastic tarp that covers the test site. The tarp was installed to limit infiltration of precipitation, but with time, holes have developed in the plastic, and the tarp may now play a more significant role in limiting near-surface evaporation.

Even though the gas-injection tests initially altered the humidity in some of the test intervals, all intervals rapidly returned to their equilibration trends following testing. Overall, the pneumatic testing had little if any effect on the moisture content of the rock.

\section{PNEUMATIC TESTING - RESULTS AND DISCUSSION}

\section{Single-Hole Pneumatic Testing - Results and Discussion}

The permeability results of the three analysis methods for the single-hole gas-injection tests conducted in December 1990, are presented in table 3. Tests are numbered in order of testing. Average permeability values for the different analysis methods are: steady state, $18.69 * 10^{-16} \mathrm{~m}^{2}$; semilog, $7.14 * 10^{-16} \mathrm{~m}^{2}$; and type curve, $6.04 * 10^{-16} \mathrm{~m}^{2}$. The coefficients of variation for the different test methods are: steady state, 0.09; semilog, 0.09; and type curve, 0.12. The steady-state method used the late-time data and assumed elliptical-flow geometry. The semilog method used the early-time transient data and assumed radial-flow geometry. The type-curve method ussed the later transient data and assumed leaky-radial geometry.

Table 3. Permeability test results of three analysis methods of single-hole gas-injection testing using air and nitrogen, December 1990

\begin{tabular}{|c|c|c|c|c|c|}
\hline \multirow[b]{2}{*}{ Test name } & \multirow{2}{*}{$\begin{array}{l}\text { Injec- } \\
\text { tion } \\
\text { rate } \\
\text { (slpm) }\end{array}$} & \multirow[b]{2}{*}{$\begin{array}{c}\text { Gas } \\
\text { type } \\
.\end{array}$} & \multicolumn{3}{|c|}{$\begin{array}{l}\text { Permeability } \\
\left({ }^{(} 10^{-16} \mathrm{~m}^{2}\right)^{1}\end{array}$} \\
\hline & & & $\begin{array}{l}\text { Steady- } \\
\text { state } \\
\text { analysis }\end{array}$ & $\begin{array}{l}\text { Semi- } \\
\text { log } \\
\text { anal- } \\
\text { ysis }\end{array}$ & $\begin{array}{c}\text { Type- } \\
\text { curve } \\
\text { analysis }\end{array}$ \\
\hline Test 1 & 5.0 & Air & 20.3 & 6.4 & 5.1 \\
\hline Test 2 & 1.0 & Air & 16.7 & 6.4 & 5.5 \\
\hline Test 3 & 3.0 & Air & 19.7 & 6.9 & 5.7 \\
\hline Test 4 & 1.0 & $N$ & 15.4 & 6.7 & 5.6 \\
\hline Test 5 & 3.0 & $N$ & 18.7 & 7.4 & 6.6 \\
\hline Test 6 & 5.0 & $N$ & 20.3 & 8.1 & 7.3 \\
\hline Test 7 & 8.0 & $\mathrm{~N}$ & 19.8 & 8.1 & 6.5 \\
\hline Mean & & & 18.69 & 7.14 & 6.04 \\
\hline $\begin{array}{l}\text { Standard } \\
\text { deviation }\end{array}$ & & & 1.78 & 0.68 & 0.72 \\
\hline $\begin{array}{l}\text { Coefficient } \\
\text { of varia- } \\
\text { tion }\end{array}$ & & & 0.09 & 0.09 & 0.12 \\
\hline
\end{tabular}

Log-log plots of the pressure-squared differences as a function of time had a unit slope during the first 1 to 2 minutes. The unit slope is interpreted to be due to well-bore storage. Because of the effects of early period well-bore storage on the test results, the first 1 to 
2 minutes of data were not used in the analysis. Attempts to match the data to type curves that included well-bore storage were unsuccessful in defining the correct storage values, and therefore, the data, excluding the first one to two minutes of the test, were matched to the Ramey (1967) radial-flow type curve. A $\log -\log$ plot of the pressure-squared differences as a function of time of the injection interval during Test 6 is presented in figure 7; it is typical of the single-hole testing injection interval plots. The plot of the early data is a 1:1 slope indicating well-bore storage. The intermediate data matches the Ramey radial-flow type curve, and the later data could be interpreted to be due to partial penetration or a constant head boundary. The Ramey line-source radial-flow type curve and the van Everdingen and Hurst (1949) type curve for radial flow with the dimensionless radius equal to 1.0 are shown for reference. On the basis of surface-geologic mapping and television camera logs from the bore- holes, it was known that the nonfractured test interval was bounded by both near-vertical and near-horizontal fractures. It was probable that one or more of these fractures were a constant head boundary during testing.

Maximum differences among analysis methods are: steady-state, 22 percent; semilog, 26 percent; and type curve, 43 percent. The semilog permeability values range from 16 to 25 percent larger than the typecurve permeability values. Steady-state analysis gave permeability values that are two or three times greater than those obtained by semilog and type-curve methods. This was probably because one or more fractures acted as a constant head boundary. As mentioned, the tuff is fractured and the single-hole test interval was located between the fractures. The distance between the test interval and a fracture controls how soon during a test the fracture becomes a constant head boundary. In this testing, the early time transient data were not affected, however, the latter time steady-state data were

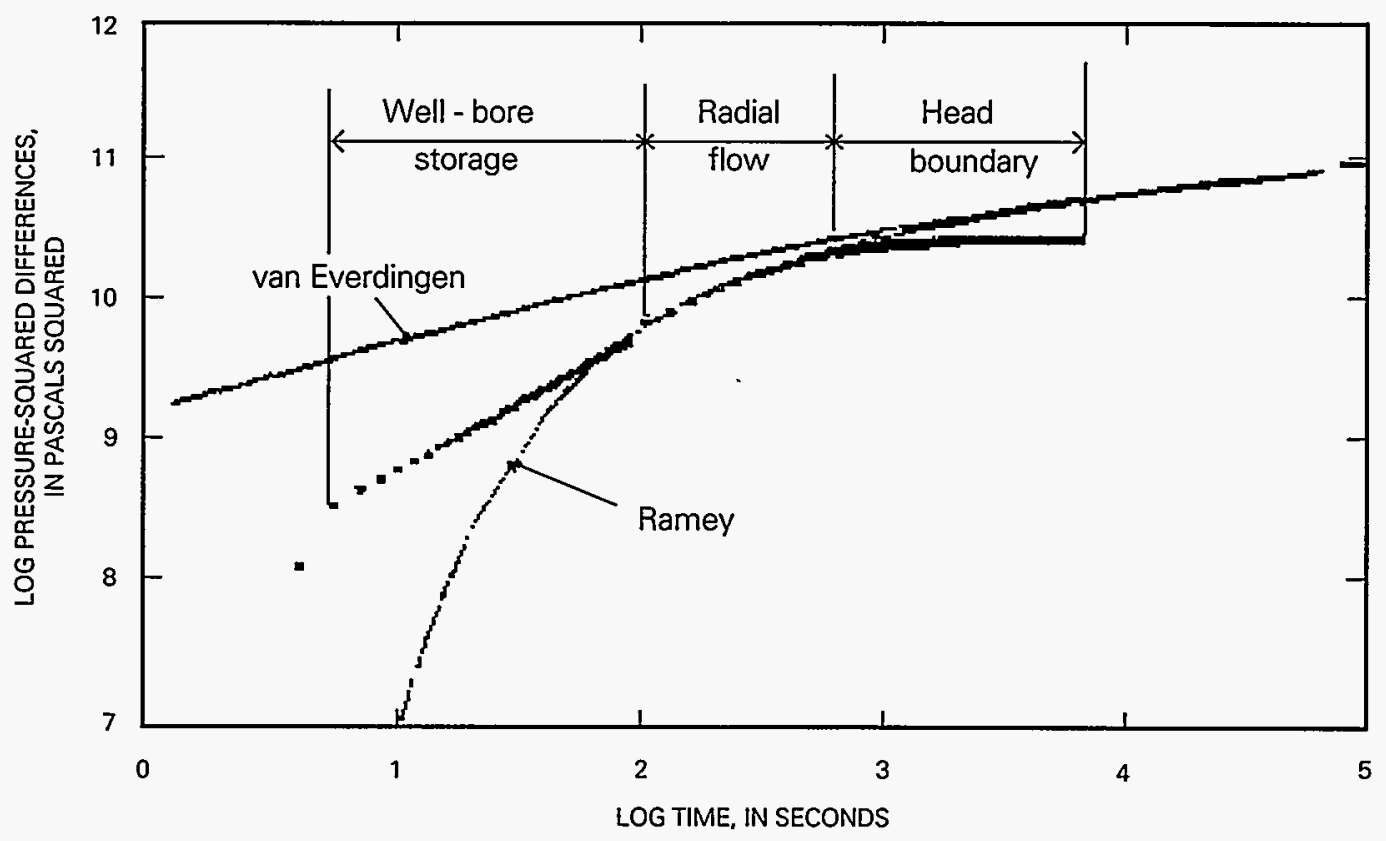

Figure 7. Log-log plot of the pressure-squared differences with time of the injection interval during single-hole gas-injection test Test 6, and the Ramey (1967) and van Everdingen and Hurst (1949) type curves. 
affected. The semilog and type-curve results compare very well with the in-situ test results of Rasmussen and others (1989), whose air-injection testing of the same interval in borehole $\mathrm{Y}-2$ resulted in permeability values between 4.26 and $10.98 * 10^{-16} \mathrm{~m}^{2}$.

The F-distribution significance test results and p-values, for a two-way analysis of variance of the single-hole test permeability values using paired identical-rate injection rates of air and nitrogen, are shown in table 4. The significance test among injection rates determines if the variance among all the gas-injection test permeability values, analyzed by a single method, are significant, or could the different permeability values be due to normal random variation that is found in most populations? Using a significance level of what was probably .05 (5 percent probability of a false positive), the variance was significant only among injection rates analyzed by the steady-state method. The significance test between gases determines if the variance between air-injection test permeability values and identical-rate nitrogen-injection test permeability values, analyzed by the same method, are significant, or could the different permeability values be due to normal random variation? Using a significance level of .05 , none of the analysis methods had a statistically significant variance.

Table 4. F-distribution significance at the 0.05 level, and p-values, for a two-way analysis of variance of single-hole testing permeability values using paired injection rates of air and nitrogen

\begin{tabular}{lccc}
\hline \multirow{2}{*}{ Significance test } & \multicolumn{3}{c}{ Significance results } \\
\cline { 2 - 4 } & $\begin{array}{c}\text { Steady- } \\
\text { state } \\
\text { analysis }\end{array}$ & $\begin{array}{c}\text { Semilog } \\
\text { analysis }\end{array}$ & $\begin{array}{c}\text { Type- } \\
\text { curve } \\
\text { analysis }\end{array}$ \\
\hline Among injection rates & Yes (.02) & No (.19) & No (.68) \\
Between gases & No (.19) & No (.09) & No (.22) \\
\hline
\end{tabular}

The single-hole testing correlation coefficients, and $t$-test significance at the 0.05 level, for injectionrate with permeability and test order with permeability, are shown in table 5. The analysis indicates a significant correlation between injection rate and permeability values determined by steady-state and semilog methods, and a significant correlation between test order and permeability values determined by semilog and type-curve methods. The significant correlation coefficients between the injection rate and permeability values indicate that the permeability increased with larger injection rates. The significant correlation coefficients between test order and permeability values indicate that the permeability increased during the testing period.

Table 5. Correlation coefficients, and t-test significance at the 0.05 level, of injection rate with permeability and test order with permeability for single-hole gas-injection testing

\begin{tabular}{lccc}
\hline & \multicolumn{3}{c}{$\begin{array}{c}\text { Correlation coefficient and } \\
\text { (t-test significance) }\end{array}$} \\
\cline { 2 - 4 } Correlation test & $\begin{array}{c}\text { Steady- } \\
\text { state } \\
\text { analysis }\end{array}$ & $\begin{array}{c}\text { Semilog } \\
\text { analysis }\end{array}$ & $\begin{array}{c}\text { Type- } \\
\text { curve } \\
\text { analysis }\end{array}$ \\
\hline $\begin{array}{c}\text { Injection rate with } \\
\text { permeability }\end{array}$ & 0.78 (Yes) & 0.69 (Yes) & $0.42(\mathrm{No})$ \\
$\begin{array}{c}\text { Test order with } \\
\text { permeability }\end{array}$ & $0.18(\mathrm{No})$ & 0.94 (Yes) & 0.87 (Yes) \\
\hline
\end{tabular}

The air permeability of a rock will vary as a function of water content; therefore, each permeability value has an associated capillary pressure. During initial single-hole testing, the thermocouple psychrometers were not operating, and therefore, measurement of the relative humidity and subsequent estimate of the water potential and capillary pressure was not possible; however, later cross-hole testing thermocouplepsychrometer data indicate that the rock was near saturation.

During gas-injection testing, when the gas injection pressures exceed the capillary pressure in the rock, water may be forced out of the pores, thereby, increasing the permeability. Rasmusen and others (1989) show the pore sizes of the Apache Leap tuffs to range from $.01 \mu \mathrm{m}$ up to $10 \mu \mathrm{m}$. Substituting the maximum and minimum single-hole test differential pressures, 34.5 and $143.1 \mathrm{kPa}$, into the capillary equation, the associated pore diameters are 8.2 and $2.0 \mu \mathrm{m}$. Because these pore diameters are in the range of the Apache Leap Tuff pore distribution, it is possible that the gas injection testing forced water out of some pores, thereby, increasing the permeability.

Examination of the calculated permeability values in relation to their test order does not support the forced water theory. During the single-hole testing, a gas-injection rate of $5 \mathrm{slpm}$ (Test 1) was followed by tests at $1,3,1$, and 3 slpm. The forced water theory does not explain why the later, lower, flow-rate tests resulted in lower permeability values. If it was only due to increased pore space, we would expect the later, lower, flow-rate tests to still produce similar permeability values as those obtained in the first test. This does not exclude the possibility that during the overnight period between testing, the rock may have equilibrated 
and water may have reentered the pores that earlier testing had dried.

The transient data-analysis methods (semilog and type curve) had injection order with permeability correlation coefficients of 0.94 and 0.87 (table 5). The correlation between injection order and permeability indicates that permeability values increased with testing regardless of the injection rate. One possible explanation is evaporation. During testing, the gas, being dryer than the downhole in-situ air, will decrease the relative humidity and increase evaporation. The evaporation might result in increased pore space and increased gas permeability. This would occur regardless of the injection rate, although it would be a function of the injection rate and the difference between the injection gas and in-situ air relative humidity values. The rate-permeability correlation may be only a side result of an order-permeability correlation caused by the failure to randomize the test flow rates during the nitrogen-injection testing.

Other possible explanations of the correlations are that they are: due to the assumptions used to simplify the physics of the flow systems, due to the simplifications of the mathematics of the system, or they may simply be due to the small data base. Regardless of the actual cause, the testing indicates that the differences in calculated permeability values are greater between different analysis methods than between flow rates or gas types.

Analysis of the thermistor data indicates that the isothermal assumptions required to deal with gas viscosity and density are reasonable. However, the matrix permeability values are in the range that the Klinkenberg effect would be expected to affect the test results. In addition, the question of turbulence or inertial forces should also be considered; these factors will cause calculated permeability values to decrease with increasing injection rates.

\section{Cross-Hole Pneumatic Testing - Results and Discussion}

The permeability results of the cross-hole gasinjection and recovery tests conducted in May 1991, are presented in table 6 . Electrical problems with the mass-flow controller during test Inject 4 prevented analysis. The injection-interval data (I2) were analyzed by steady-state, type-curve, and semilog methods; monitor intervals were analyzed by a type-curve method.
Table 6. Permeability test results of cross-hole gas-injection and recovery testing, May 1991

\begin{tabular}{|c|c|c|c|c|c|c|}
\hline \multirow{3}{*}{$\begin{array}{c}\text { Test } \\
\text { name }\end{array}$} & \multirow{3}{*}{$\begin{array}{c}\text { Injec- } \\
\text { tion } \\
\text { rate } \\
\text { (slpm) }\end{array}$} & \multicolumn{5}{|c|}{$\begin{array}{c}\text { Permeability } \\
\left({ }^{*} 10^{-14} \mathrm{~m}^{2}\right)\end{array}$} \\
\hline & & \multicolumn{3}{|c|}{ Injection interval 12} & \multicolumn{2}{|c|}{$\begin{array}{l}\text { Monitor } \\
\text { intervals }\end{array}$} \\
\hline & & $\begin{array}{l}\text { Steady- } \\
\text { state } \\
\text { anal- } \\
\text { ysis }\end{array}$ & $\begin{array}{l}\text { Type- } \\
\text { curve } \\
\text { anal- } \\
\text { ysis }\end{array}$ & $\begin{array}{l}\text { Semi- } \\
\text { log } \\
\text { anal- } \\
\text { ysis }\end{array}$ & M1 & M2 \\
\hline Inject 1 & 50.0 & 3.61 & 2.53 & 2.70 & 1.82 & 0.81 \\
\hline Recov 1 & - & -- & 1.89 & 3.39 & 1.89 & 0.88 \\
\hline Inject 2 & 23.6 & 3.49 & * & $*$ & 1.94 & 0.95 \\
\hline Recov 2 & - & - & 2.51 & 2.87 & 1.79 & 0.95 \\
\hline Inject 3 & 74.8 & 3.68 & 1.47 & 2.94 & 1.81 & 0.88 \\
\hline Recov 3 & - & - & 1.41 & 2.94 & 1.96 & 0.99 \\
\hline Inject 5 & 12.7 & 3.62 & 1.25 & 2.14 & 1.81 & 0.84 \\
\hline Recov 5 & $\cdot \quad-$ & -- & $*$ & 1.83 & 1.67 & 0.91 \\
\hline Inject 6 & 98.6 & 3.80 & 3.49 & 3.22 & 1.59 & 0.87 \\
\hline Mean & & 3.64 & 2.08 & 2.75 & 1.81 & 0.90 \\
\hline $\begin{array}{l}\text { Standard } \\
\text { devia- } \\
\text { tion }\end{array}$ & & 0.11 & 0.75 & 0.49 & 0.11 & 0.05 \\
\hline $\begin{array}{l}\text { Coeffi- } \\
\text { cient of } \\
\text { variation }\end{array}$ & & 0.03 & 0.36 & 0.18 & 0.06 & 0.06 \\
\hline
\end{tabular}

Calculated permeability values ranged from $0.81 * 10^{-14} \mathrm{~m}^{2}$ to $3.80 * 10^{-14} \mathrm{~m}^{2}$. The coefficients of variation ranged from 0.06 for both the monitorintervals type-curve analysis, and up to 0.36 for the injection-interval type-curve analysis. Permeability values from the cross-hole pneumatic testing are from 1 to 2 orders of magnitude larger than those obtained in the single-hole testing. This is because the single-hole test interval was located in a nonfractured zone while the cross-hole injection interval was located on a fractured zone.

The injection-interval data best matched a type curve for a leaky aquifer with $\mathrm{v}=0.25$ as defined by Cooper (1963) or $\mathrm{r} / \mathrm{B}=0.5$ as defined by Hantush and Jacob (1955). Figure 8 shows a log-log plot of the pressure-squared differences as a function of time, of the injection interval during test Inject 3 , matched with the Cooper type curve where $v=0.25$; it is a typical injection-interval pressure-squared differences plot. The injection-interval data plots show no well-bore storage effects. The nonleaky $(v=0.0)$ radial-flow type curve is shown as a reference. The monitor-interval data best matched the Carslaw and Jaeger (1959) spherical flowtype curve. Figure 9 shows a log-log plot of the pres- 


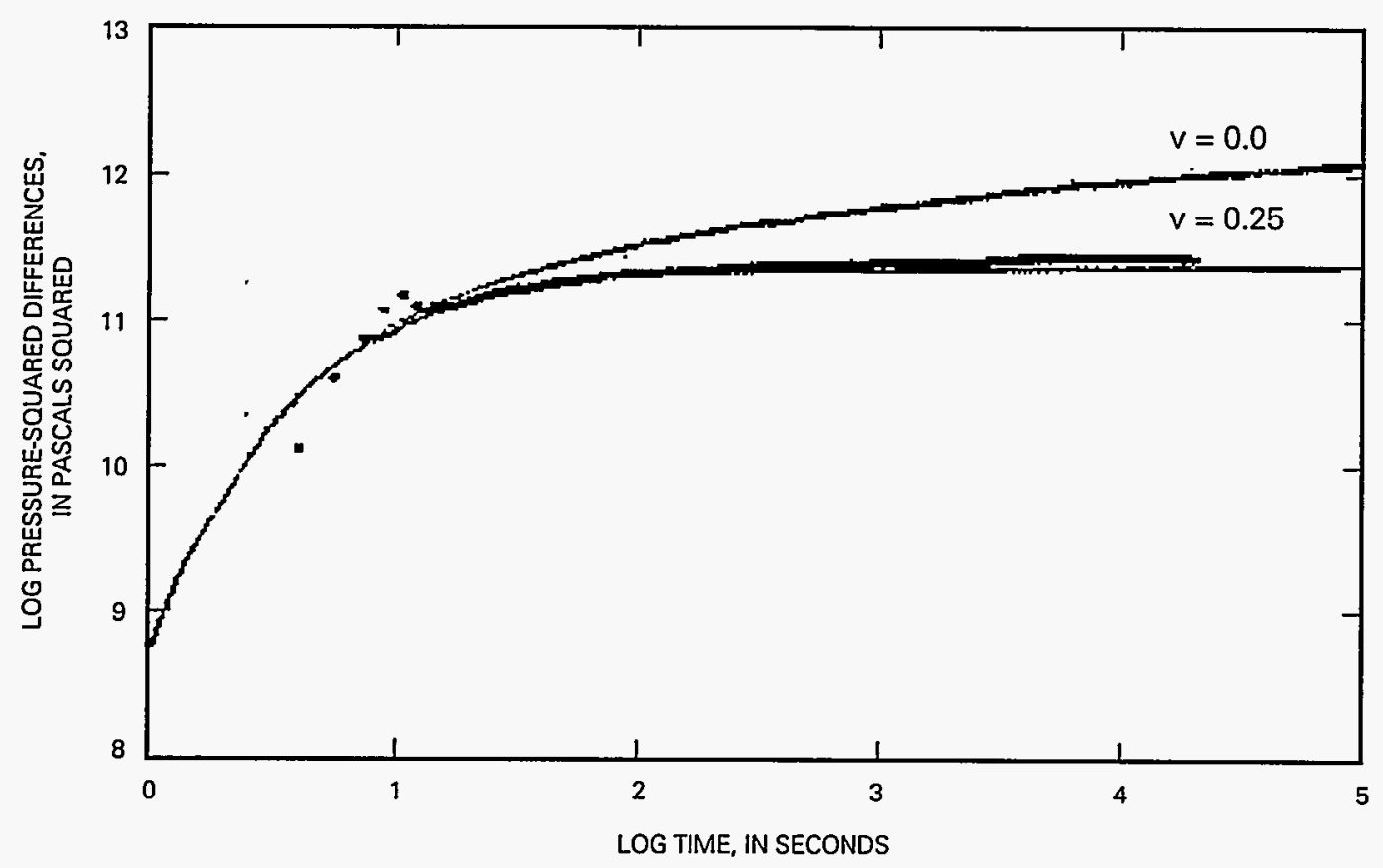

Figure 8. Log-log plot of the pressure-squared differences with time of the injection interval during cross-hole gas-injection test Inject 3, and the Cooper (1963) type curves for $v=0.0$ and $v=0.25$.

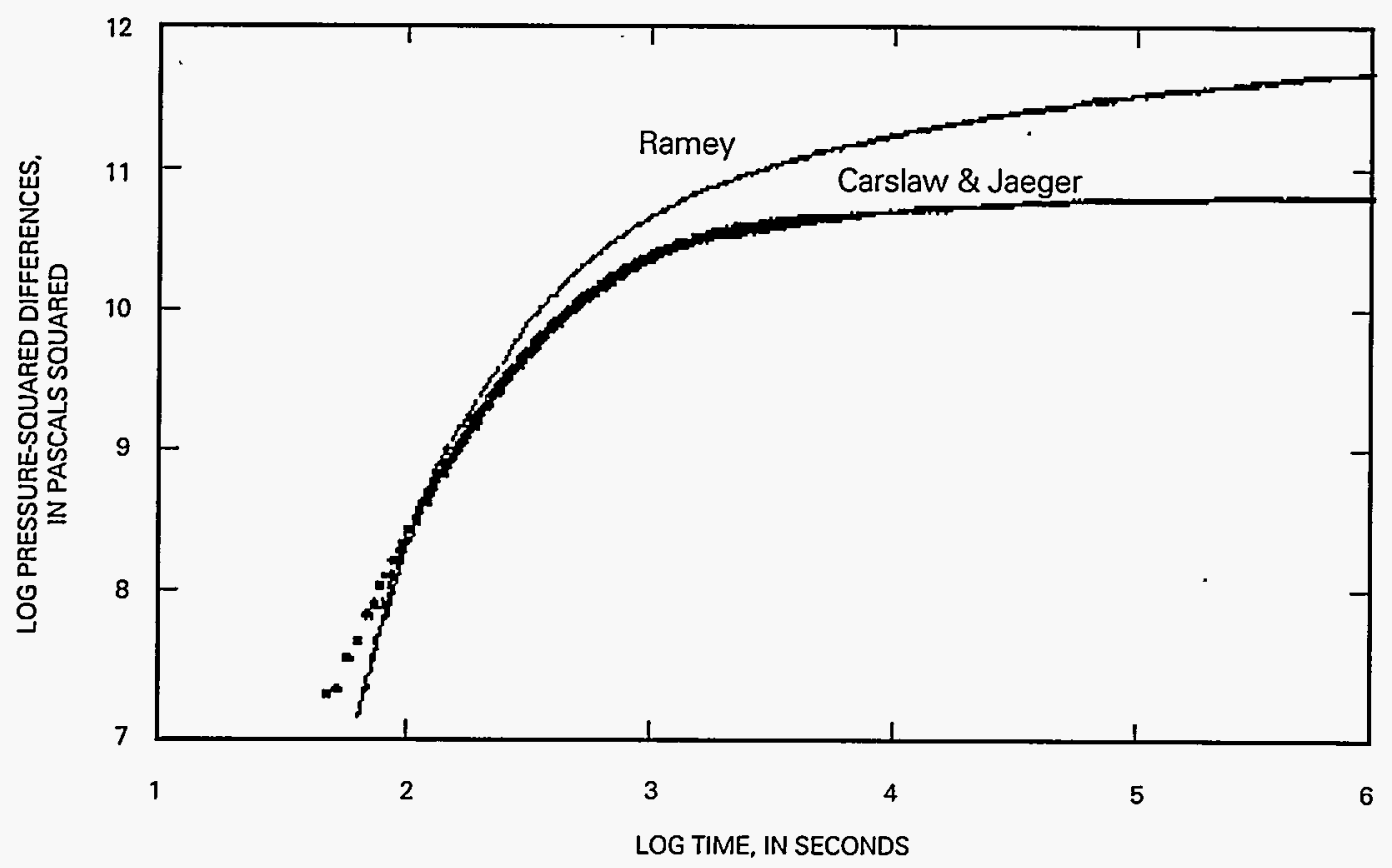

Figure 9. Log-log plot of the pressure-squared differences with time of monitor interval M1 during gas-injection test Inject 3 and the Carslaw and Jaeger (1959) spherical-flow and the Ramey (1967) radial-flow type curves. 
sure-squared differences as a function of time, of monitor interval M1, test Inject 3, matched with the spherical flow-type curve; it is a typical monitorinterval pressure-squared differences plot. The Ramey (1967) radial-flow type curve is shown as a reference.

Figure 10 shows a typical semilog plot of the injection-interval pressure-squared differences as a function of time during test Inject 3 . The semilog analysis of the injection interval used only the straight line part of the data that was collected during the initial 80 seconds of the test. After approximately $80 \mathrm{sec}-$ onds, data diverged from the straight-line plot in a response more typical of a leaky aquifer.

The plots of the pressure-squared differences as a function of time show that during cross-hole testing the flow geometry changed. During the early period (first 1 to 2 minutes), the flow was confined to a single perpendicular fracture, and therefore, the flow was radial; as the area of influence becomes larger, the flow system began to intercept more fractures, and the flow geometry resembled that of a leaky aquifer. As the flow system became larger and intercepted more fractures, the flow geometry changed to spherical. This changing flow geometry is why the three different analysis methods of the injection interval give similar permeability values. Each of the different analysis methods uses a flow model and data that are correct for a select time period. The steady-state method used the late-time data and assumed elliptical flow geometry. The semilog method used the early-time transient data and assumed radial-flow geometry. The type curve method used the later transient data and assumed leaky radial geometry. The monitor intervals (M1 and M2) were analyzed by a type-curve method assuming spherical-flow geometry.

The F-distribution significance test results and p-values, for a two-way analysis of variance of permeability values using paired gas injection and recovery tests, are shown in table 7. The significance test among injection rates determines if the variance among all the gas-injection test-permeability values, analyzed by a single method, are significant, or could the different

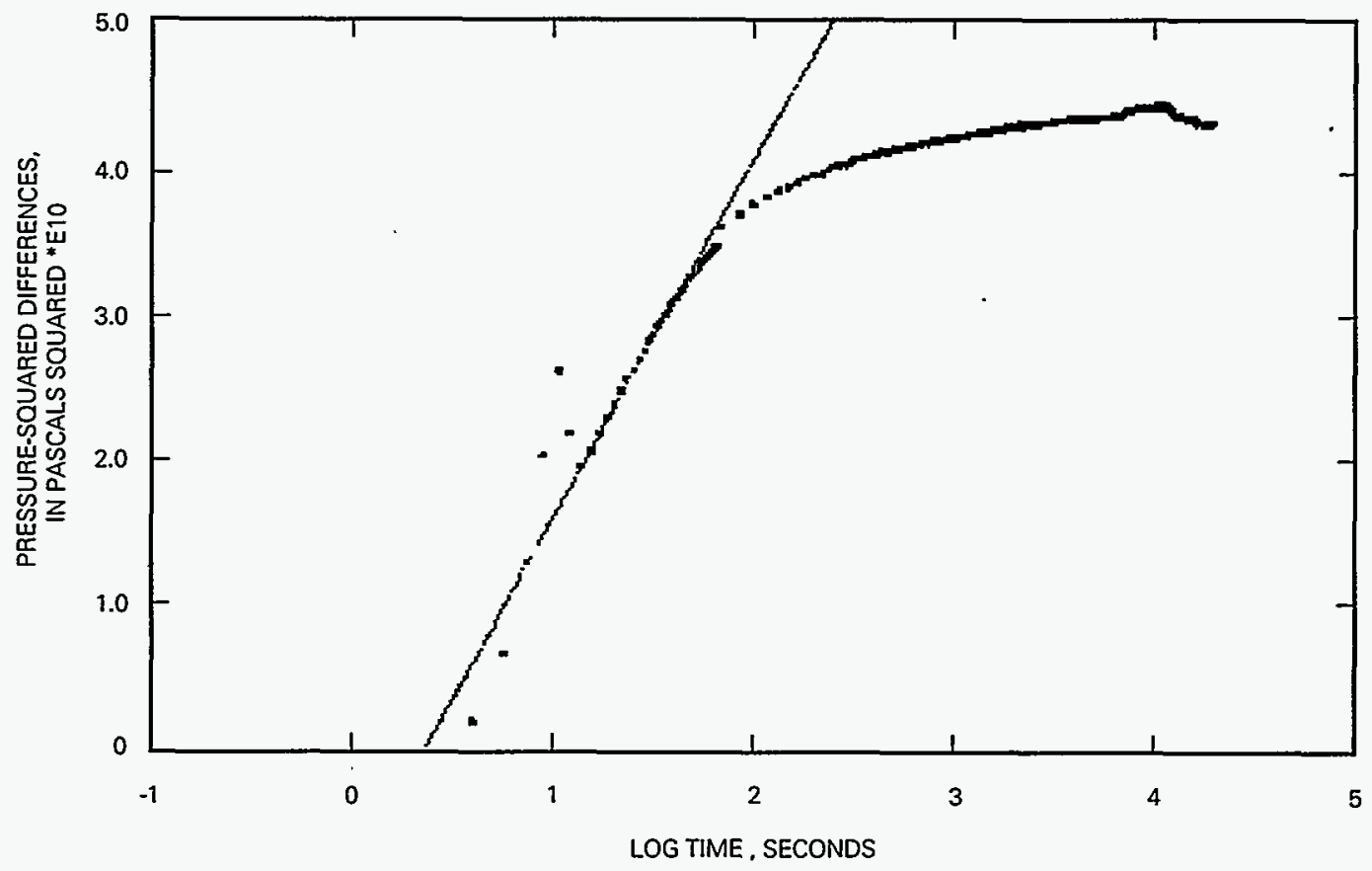

Figure 10. Semilog plot of the pressure-squared differences with time of the injection interval during test Inject 3 showing the straight-line radial flow period. 
permeability values be due to normal random variation that is found in most populations? Using a significance level of .05 ( 5 percent probability of a false positive), the variance among injection rates are not significant. The significance test between test methods determines if the variance between gas-injection tests permeability values and their associated recovery-tests permeability values are significant, or are the differences due to normal random variation that is found in most populations? Using a significance level of .05 , the variance between test methods are not significant.

Table 7. F-distribution significance at the 0.05 level, and p-values, for a two-way analysis of variance of cross-hole testing permeability values using paired gas-injection and recovery tests

\begin{tabular}{cccccc}
\hline & \multicolumn{4}{c}{ Significance results } \\
\cline { 2 - 6 } $\begin{array}{c}\text { Significance } \\
\text { test }\end{array}$ & \multicolumn{3}{c}{ Injection interval } & \multicolumn{1}{c}{$\begin{array}{c}\text { Monitor } \\
\text { intervals }\end{array}$} \\
\cline { 2 - 6 } & $\begin{array}{c}\text { Steady- } \\
\text { state }\end{array}$ & $\begin{array}{c}\text { Type- } \\
\text { curve }\end{array}$ & $\begin{array}{c}\text { Semi- } \\
\text { log }\end{array}$ & & \\
& anal- & anal- & anal- & M1 & M2 \\
& ysis & ysis & ysis & & \\
\hline Among injec- & $*$ & $*$ & No & No & No \\
tion rates & & & $(.16)$ & $(.59)$ & $(.12)$ \\
Between test & $*$ & $*$ & No & No & No \\
methods & & & $(.71)$ & $(.83)$ & $(.07)$ \\
\hline
\end{tabular}

* Insufficient number of pairs for analysis.

The cross-hole testing correlation coefficients and t-test significance at the 0.05 level, for injection rate with permeability and test order with permeability, are shown in table 8. The correlation analysis indicates a significant correlation between injection rates and permeability values for the steady-state and semilog analysis of the injection interval. Any conclusions on correlations must be tempered with the fact that the variance analysis indicates no significant difference between rates or test methods. Examination of the permeability values, especially the steady-state permeability values, indicates that you can have a high correlation yet there may not be any real difference between the values. The small data base may be the cause of the significant correlations

Analysis of the thermocouple-psychrometer data indicates that the monitor and guard intervals were condensing water during the cross-hole testing. It is possible that the test intervals contained sufficient moisture that water might obstruct the fracture paths, and that gas injection could have forced the water from the fractures and increased the permeability. In addition, the 0.69 correlation coefficient of injection order with permeability may not be significant at a .05 level, but it is still a relatively high correlation. As in the single-hole testing, there may be some relation between gas testing and increased permeability in the injection interval. However, this theory is not supported by permeability values from the type-curve analysis.

Table 8. Correlation coefficients, and t-test significance at the 0.05 level, of injection rate with permeability and test order with permeability for cross-hole gas-injection and recovery testing

\begin{tabular}{|c|c|c|c|c|c|}
\hline \multirow{4}{*}{$\begin{array}{c}\text { Correlation } \\
\text { test }\end{array}$} & \multicolumn{5}{|c|}{$\begin{array}{l}\text { Correlation coefficient and } \\
\text { (t-test significance) }\end{array}$} \\
\hline & \multicolumn{3}{|c|}{ Injection interval } & \multirow{2}{*}{\multicolumn{2}{|c|}{$\begin{array}{l}\text { Monitor } \\
\text { intervals }\end{array}$}} \\
\hline & \multicolumn{3}{|c|}{12} & & \\
\hline & $\begin{array}{l}\text { Steady- } \\
\text { state } \\
\text { anal- } \\
\text { ysis }\end{array}$ & $\begin{array}{l}\text { Type- } \\
\text { curve } \\
\text { anal- } \\
\text { ysis }\end{array}$ & $\begin{array}{l}\text { Semi- } \\
\text { log } \\
\text { anal- } \\
\text { ysis }\end{array}$ & M1 & M2 \\
\hline $\begin{array}{l}\text { Injection rate } \\
\text { with perme- } \\
\text { ability }\end{array}$ & $\begin{array}{l}0.84 \\
\text { (Yes) }\end{array}$ & $\begin{array}{l}0.38 \\
\text { (No) }\end{array}$ & $\begin{array}{r}0.73 \\
(Y e s)\end{array}$ & $\begin{array}{l}-0.16 \\
\text { (No) }\end{array}$ & $\begin{array}{l}-0.04 \\
\text { (No) }\end{array}$ \\
\hline $\begin{array}{l}\text { Test order with } \\
\text { permeability }\end{array}$ & $\begin{array}{l}0.69 \\
\text { (No) }\end{array}$ & $\begin{array}{l}0.15 \\
\text { (No) }\end{array}$ & $\begin{array}{l}-0.36 \\
\text { (No) }\end{array}$ & $\begin{array}{l}-0.64 \\
\text { (No) }\end{array}$ & $\begin{array}{l}0.12 \\
\text { (No) }\end{array}$ \\
\hline
\end{tabular}

Overall, the analysis of variance and correlation coefficients indicates that for the flow range tested, the monitor-interval permeability values are not dependent on test method, injection rate, or test order. The significant correlation coefficients of the injection interval, along with the condensing water vapor measured by the thermocouple psychrometer, indicate that the injection interval permeability values may have been influenced by testing. However, considering that the gasinjection rates ranged up to nearly one order of magnitude (12.7 to 98.6 ), the coefficients of variation are small.

The porosity values from the cross-hole gasinjection and recovery testing conducted in May 1991, are presented in table 9 . The monitor-interval porosities are from the spherical flow-model type-curve analysis. Monitor intervals M1 and M2 had average porosity values of 1.8 and 0.9 percent. Monitor interval M1 porosity values are twice that of M2. The coefficients of variation are 0.06 and 0.07 . 
Table 9. Porosity values from cross-hole gas-injection and recovery testing, May 1991

\begin{tabular}{lccc}
\hline & $\begin{array}{c}\text { Injection } \\
\text { rate }\end{array}$ & \multicolumn{2}{c}{$\begin{array}{c}\text { Porosity } \\
\text { (percent) }\end{array}$} \\
\cline { 3 - 4 } & (slpm) & \multicolumn{2}{c}{ Monitor intervals } \\
\cline { 3 - 4 } & & M1 & M2 \\
\hline Inject 1 & 50.0 & 1.8 & 0.9 \\
Recov 1 & - & 1.7 & 0.9 \\
Inject 2 & 23.6 & 1.8 & 0.9 \\
Recov 2 & - & 1.8 & 1.0 \\
Inject 3 & 74.8 & 1.7 & 0.9 \\
Recov 3 & - & 1.8 & 1.0 \\
Inject 5 & 12.7 & 1.8 & 0.9 \\
Recov 5 & -- & 2.0 & 1.0 \\
Inject 6 & 98.6 & 1.6 & 0.8 \\
\hline Mean & & 1.78 & 0.92 \\
Standard deviation & & 0.10 & 0.06 \\
Coefficient of variation & & 0.06 & 0.07 \\
\hline
\end{tabular}

The F-distribution significance test results and p-values, for a two-way analysis of variance of porosity values using paired identical-rate gas-injection and recovery tests, are shown in table 10 . The significance test among injection rates determines if the variance among the porosity values of all the gas-injection and recovery tests for an individual monitor interval, are significant, or could the different porosity values be due to normal random variation that is found in most populations? At the .05 level of significance, the variance among the different injection rates was not significant. The significance test between test methods determines if the differences between the gas-injection tests porosity values and their subsequent recovery tests porosity values are significant, or are the different porosity values due to normal random variation that is found in most populations? At the .05 level of significance, the variance between test methods was not significant.

Table 10. F-distribution significance at the 0.05 level, and $p$-values, for a two-way analysis of variance of porosity using paired gas-injection and recovery tests

\begin{tabular}{ccc}
\hline \multirow{2}{*}{ Significance test } & \multicolumn{2}{c}{ Monitor intervals } \\
\cline { 2 - 3 } & M1 & M2 \\
\hline Among injection rates & No $(.44)$ & No $(.50)$ \\
Between test methods & No $(.49)$ & No $(.06)$ \\
\hline
\end{tabular}

The correlation coefficients and t-test significance at the 0.05 level, for injection rate with porosity and test order with porosity, are shown in table 11. The only significant correlation was injection rate with porosity for monitor interval M1. Examination of the data in table 9 indicates that the significant correlation was possibly due to the small range of porosity values for M1 (1.6 to 2.0 percent).

Table 11. Correlation coefficients, and t-test significance at the 0.05 level, of injection rate with porosity and test order with porosity for cross-hole gas-injection and recovery testing

\begin{tabular}{lcc}
\hline \multirow{2}{*}{ Correlation test } & \multicolumn{2}{c}{$\begin{array}{c}\text { Correlation coefficient and } \\
\text { (T-test significance) }\end{array}$} \\
\cline { 2 - 3 } & \multicolumn{2}{c}{ Monitor intervals } \\
\cline { 2 - 3 } & $M 1$ & $M 2$ \\
\hline Injection rate with porosity & $-0.75(\mathrm{Yes})$ & $-0.49(\mathrm{No})$ \\
Injection order with porosity & $-0.04(\mathrm{No})$ & $-0.07(\mathrm{No})$ \\
\hline
\end{tabular}

Overall, the two-way analysis of variance and correlation analysis of the monitor-intervals porosities indicate that the calculated porosity was not dependent on test method, injection rate, or test order. The -0.75 correlation of injection rate/porosity was probably due to the small data base.

\section{SUMMARY}

\section{Thermistors}

Thermistors were used to monitor downhole temperatures in all test intervals during pneumatic testing of ash-flow tuff. Single-hole testing was conducted in nonfractured tuff during December 1990, and crosshole testing was conducted in fractured tuff during May 1991. Temperature monitoring showed significant correlations between the temperature change in the injection interval and the gas-injection rate.

The December 1990 pre-test temperatures had a temperature gradient of $0.4^{\circ} \mathrm{C}$ per meter of vertical depth. The May 1991 pre-test temperatures had no gradient. The December pre-test temperature gradient is probably the result of near-surface, residual summerheat storage. The maximum temperature fluctuations, during both single and cross-hole testing, were in the injection interval. Maximum downhole temperature variation in the injection interval during single-hole testing was $0.4^{\circ} \mathrm{C}$. The maximum downhole temperature variation in the injection interval during cross-hole . testing was $1.2^{\circ} \mathrm{C}$. The maximum temperature fluctuations in the guard and monitor intervals, during both 
single and cross-hole testing, were $0.1^{\circ} \mathrm{C}$. At the completion of a testing, temperatures in all intervals were within $0.1^{\circ} \mathrm{C}$ of their pre-test temperatures.

Temperature changes measured in the downhole intervals were the result of both gas expansion and the temperature of the injection gas. The larger temperature changes measured were the result of gas expansion during the initial period of the recovery tests. Using the maximum temperature change, the maximum effect of fluctuating temperature on the calculated permeability values is less than 4 percent. Overall, the thermistors indicate that the temperature changes had no adverse effects on the pneumatic testing and calculated permeability values for the injection ranges and associated pressure increases tested.

\section{Thermocouple Psychrometer}

Thermocouple psychrometers were used to monitor relative-humidity values in the guard and monitor intervals during pneumatic testing. The thermocouple psychrometers did not operate during the December 1990 single-hole testing. During the May 1991 crosshole testing, the test intervals were at or near saturation. The negative voltage outputs of the thermocouplepsychrometer dry bulbs indicate that water vapor was condensing in the test intervals; this means that the relative humidities of the intervals were greater than saturation. After an initial increase in water-vapor condensation during the early hours of testing, the test intervals began to equilibrate; however, none of the intervals were ever dry enough for the thermocouple psychrometer to measure the relative humidity. The guard and monitor intervals had decreased condensation during some of the air-injection tests, indicating influence from the dryer-injected air. When gas injection was halted, the lower guard interval had higher condensation than before the gas injection. This increased condensation was due to the decreased temperature associated with the gas expansion during the recovery tests.

Even though the gas injection altered the humidity in some of the test intervals, all intervals rapidly returned to their equilibration trends following any perturbations. Overall, the thermocouple psychrometers show that the pneumatic testing had little, if any, effect on the rock-moisture content.

\section{Single-Hole Pneumatic Testing}

Single-hole pneumatic testing was conducted on an interval of nonfractured tuff using downhole inflatable packers. The pneumatic testing was limited to gas-injection testing. Test gases were humidified air and dry nitrogen. Injection-test rates ranged from 1.0 to $8.0 \mathrm{slpm}$. Plots of the pressure-squared differences with time show a period of well-bore storage during the early time period of the tests.

The pressure data were analyzed by steady-state, semilog, and type-curve methods. Average permeability values calculated using the different analysis methods are: steady state, $18.69 * 10^{-16} \mathrm{~m}^{2}$; semilog, $7.14 * 10^{-16} \mathrm{~m}^{2}$; and type curve, $6.04 * 10^{-16} \mathrm{~m}^{2}$. The permeability values determined from the steady-state analysis are several multiples larger than those determined from the transient analysis. This may be due to a fracture acting as a constant head boundary; the early time transient data were not affected, however, the latter time steady-state data were affected.

Statistical analysis indicates that the only statistically significant variance was among different injection rates analyzed by steady-state methods. All other variance analysis indicate that there was no difference among the different injection rates nor between the gas types.

Correlation analysis shows a significant correlation between injection rate and permeability values analyzed by steady-state and semilog methods, and a significant correlation between test-order and permeability values analyzed by semilog and type-curve methods. The correlation between the injection rate and permeability values indicates that the permeability increased with larger injection rates; however, examination of the permeability values in relation to their test order does not support this conclusion. Other possible explanations are that it is a function of the assumptions used to simplify the physics and mathematics of the system, or it may simply be due to the small data base. The correlation between injection order and permeability values indicates that permeability values increased with testing regardless of the injection rate. One possible explanation is that over the test period, evaporation removed some water from the rock pores resulting in an a small increase in permeability. The correlation between test rate and permeability may be only a side result of a test order with permeability correlation caused by the failure to randomize the test-flow rates during the nitrogen-injection testing. Whatever the actual cause, or if it is due to the small data base, testing indicates that differences in the calculated permeability values are greater between analysis methods than between flow rates or gas types. 


\section{Cross-Hole Pneumatic Testing}

Cross-hole pneumatic testing was conducted between two boreholes in fractured tuff, using downhole inflatable packers; testing included gas-injection and recovery tests. The two boreholes were parallel, in the same plane, 5 meters apart, and angled at 45 degrees off vertical. All testing was conducted using compressed air. Gas-injection rates ranged from 12.7 to $98.6 \mathrm{slpm}$. Plots of the pressure-squared differences as a function of time show no well-bore storage effects.

The pressure data were analyzed by steady-state, semilog, and type-curve methods. Calculated permeability values ranged from $0.81 * 10^{-14} \mathrm{~m}^{2}$ in the monitor intervals, up to $3.80 * 10^{-14} \mathrm{~m}^{2}$ in the injection interval, and are from 1 to 2 orders of magnitude larger than those calculated from the single-hole tests data. The higher permeability values, than those from the single-hole testing, are because the single-hole test injection interval was located in a nonfractured zone while the cross-hole injection interval was located on a fractured zone.

The plots of the pressure-squared differences as a function of time show that during cross-hole testing, the flow geometry changes from radial, to a leaky aquifer, to spherical. The changing flow geometry explains how different analysis methods, using different flow models, yield similar permeability values. Each of the different analysis methods uses a flow model and data that are correct for a select time period of a test.

Overall, the analysis of variance and correlation analysis indicates that the monitor-intervals permeability values are not dependent on test method, injection rate, or test order for the flow range tested. The significant correlations between injection-rate and permeability values, shown by the steady-state and semilog analysis of the injection interval, indicate that the injection-interval permeability values may be a function of the gas-injection rate. The thermocouple psychrometers indicate that the monitor and guard intervals were condensing water, and therefore, it is possible that the test intervals were wet enough for water to obstruct the fracture paths and that gas injection could have forced water from the fractures and increased the permeability. However, considering that the range of gas-injection rates was near one order of magnitude (12.7 to 98.6), the coefficients of variation are small.

Porosity estimates were made using the monitor intervals M1 and M2 type-curve matches. Porosity estimates ranged from 0.8 to 2.0 percent. Porosity estimates from monitor interval M1 are twice that of M2.
The two-way analysis of variance and correlation analysis of the monitor-intervals porosities indicates that the calculated porosity values are not dependent on test method, injection rate, or test order. The -0.75 correlation between gas-injection rate and porosity probably results from the limited number of tests.

\section{REFERENCES CITED}

Carslaw, H.S., and Jaeger, J.C., 1959, Conduction of heat in solids: London, Oxford University Press, $326 \mathrm{p}$.

Cooper, H.H., Jr., and Jacob, C.E., 1946, A generalized graphical method for evaluating formation constants and summarizing well-field history: American Geophysical Union Transcripts: v. 27, no. 4, p. 526-534.

Cooper, H.H., Jr., 1963, Type curves for nonsteady radial flow in an infinite leaky artesian aquifer, Bentall, Ray, comp., Shortcuts and special problems in aquifer tests: U.S. Geological Survey Water-Supply Paper 1545-C, p. C48.

Energy Resources Conservation Board, 1975, Theory and Practice of the Testing of Gas Wells (3d ed.): Calgary, Alberta, Canada, 1 v.

Hammer, D.F., and Peterson, D.W., 1968, Geology of the Magma mine area, Arizona: in Ore Deposits of the United States, 1933-1967, Graten-sales Volume J.D. Ridge Editor, American Institute of Mining, Metallurgical, and Petroleum Engineers, Inc., New York, 2 v.

Hantush, M.S., and Jacob, C.E., 1955, Non-steady radial flow in an infinite leaky aquifer: American Geophysical Union Transcripts, v. 36, no. 1, 95 p.

Hvorslev, M.J., 1951, Time lag and soil permeability in ground-water observations: U.S. Army Corps of Engineers, Waterways Experiment Station, Vicksburg, Miss., Bulletin no. 36,47 p.

Klinkenberg, L.J., 1941, The permeability of porous media to liquids and gases: New York, Drilling and Production Practice, American Petroleum Institute, p. 200213.

Montazer, Parviz, and Wilson, W.E., 1984, Conceptual hydrologic model of flow in the unsaturated zone, Yucca Mountain, Nevada: U.S. Geological Survey Water-Resources Investigations Report 84-4345, 55 p.

Noggle, J.H., 1985, Physical Chemistry, Little, Brown and Company, Boston, MA, p. 452.

Peterson, D.W., 1968, Zoned ash-flow sheet in the region around Superior, Arizona: Arizona Geological Society, Guidebook III, 215 p.

Peterson, N.P., 1962, Geology and ore deposits of the GlobeMiami district, Arizona: U.S. Geological Survey Professional Paper 342, $151 \mathrm{p}$. 
Ramey, H.J., Jr., 1967, Application of the line source solution to flow in porous media-A Review: Producers Monthly, May 1967, p. 25-27.

Ransome, F.L., 1903, Geology of the Globe copper district, Arizona: U.S. Geological Survey Professional Paper $12,168 \mathrm{p}$.

Rasmussen, T.C., Evans, D.D., Sheets, P.J., and Blanford, J.H., 1989, Unsaturated fractured rock characterization methods and data sets at the Apache Leap Tuff site, prepared for: Office of Nuclear Regulatory Research, U.S. Nuclear Regulatory Commission, CR-5596, 125 p.

Steinhart, J.S., and Hart, S.R., 1968, Calibration curves for thermistors: Pergamon Press, Deep-Sea Research, v. 15, p. 497-503.
U.S. Department of Commerce Weather Bureau, 1959: Climatography of the United States, no. 60-2, v.1.

van Everdingen, A.F., and Hurst, W., 1949, The application of the Laplace Transformation to flow problems in reservoirs: Petroleum Transactions, American Institute of Mining Engineers, no. 186, p. 305-324.

Weast, R.C., 1987, Editor-in-Chief, CRC Handbook of Chemistry and Physics: Boca Raton, Fla., CRC Press, Inc.

Weeks, E.P., 1977, Field determination of vertical permeability to air in the unsaturated zone, U.S. Geological Survey Open-File Report 77-346, 92 p. 
